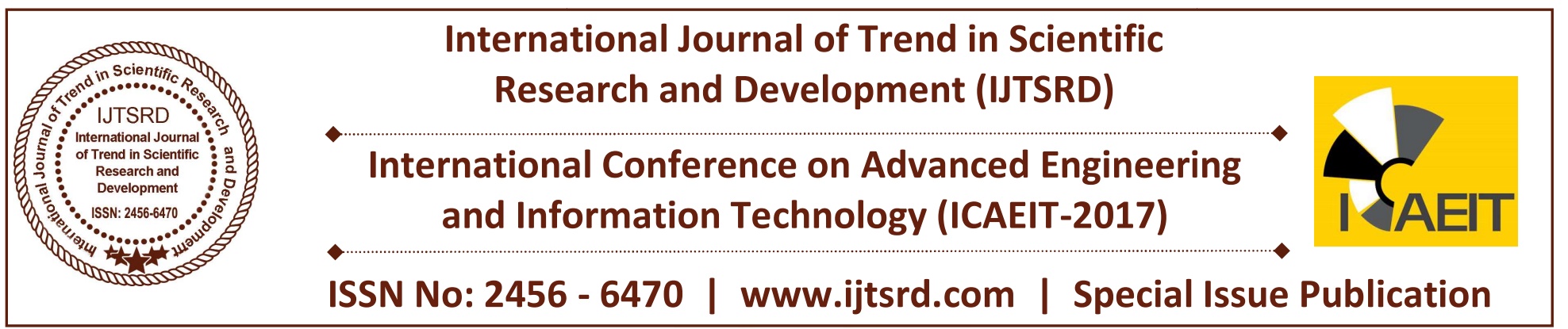

\title{
Study of Road Maintenance Fund needs Approach with Link Based and Network Based
}

\author{
Tiopan H. M. Gultom, Tamrin, Fahrul Agus \\ Mulawarman University, Samarinda, East Borneo, Indonesia
}

\section{ABSTRACT}

Dynamical systems approach can describe the process of roads pavement damage and road maintenance funding allocation scenarios. One of the important thing to predict road maintenance fund needs in the future is how to estimate the traffic that is going through in each link on the road net work. Currently the reare two ways to fore cast future traffic flow, first approaches by link based and the other is networkbased. Network-based approach requires data free flow speed of each link as an input. In dynamic, free flow speed is affected by the valueo fIRI (International Roughness Index). This paper aims to look at the differences total requirement of road maintenance funds need for each year in which the estimated future traffic flows by link-based and network-based. There are four scenarios allocation of maintenance funds in each year of analysis, ie $20 \%$, $40 \%$. $60 \%$ and $80 \%$ of the total require ment. From the analysis, it is known that the total funding need for road maintenance at the end of the estimated future traffic flows by way a network-based smaller when compared with the link based. In addition, it is known that the road maintenance fund allocation by $80 \%$ of the needs, it turns out the total funding need maintenance at the end of the analysis is the smallest.

Keywords: Link Based, Network Based, Free Flow Speed.

\section{INTRODUCTION}

Road maintenance needs can be measured quantitatively by considering rate of service standards to be achieved, butt heal location of road maintenance costs of tend not have measurable criteria. Dynamic system is very useful to understand the relationship between qualitative and quantitative aspects of road asset management. Dynamical systems approach can also describe the process of roads damage and scenarios of road maintenance funding allocation [1]. SaeidahFallah doing research whose goal is to see road maintenance funds needs are dynamically, but the her research did not look the relationship between implementation of road maintenance delay to the amount of traffic.

One of the important thing to predict maintenance fund needs in the future is how to estimate the traffic in each link in the road network. Ministry of Public Works Directorate of Highways Indonesia generally use tools HDM (Highway Development and Managemen), this tool is very helpful in predicting deterioration model and estimated road maintenance fund needs and treatment scenarios. Both of these tools are introduced by Asian Development Bankdan World Bank in early 2000. Traffic estimation method used in both this tool is Link based approaches. In Figure 1, the movement of traffic on a road network is generally as described follows.

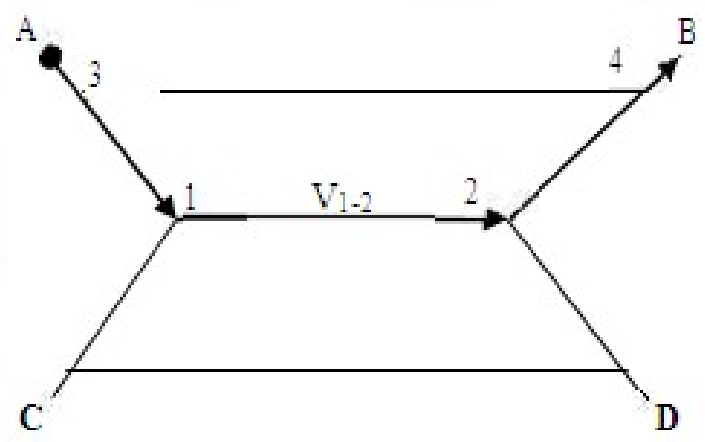

Figure1. Schematic movement from C to B through link $1-2$ 
Under normal conditions, traffic flow from $\mathrm{C}$ to Buses link 1-2, the total flow in sections $1-2$ is $\mathrm{V} 1-2$. However, if in sections 1-2 de crease din per form an cedue to road deterioration and the road cannot be repaired immediately because of limited funds, so the speed in sections 1-2 become slower and then the travel time will increase. So flow in link 1-2 will reduce. Traffic flow that comes from $\mathrm{C}$ will choose a new route that can provide faster travel time, for example, using link 3-4 towards B. Consequently, the total traffic flow in link 3-4 will increase while in link 1-2 will reduce. Link-based method cannot describe this problem. It takes survey traffic counting to validation traffic flow that has been fore casted in previous years. Consider this problem, to fore cast future traffic flow becomes in accurate if multi plying the present traffic with growth factors in link. What if the traffic estimation method in link changed by using network-based approaches, where road users are assumed will be looking fastest travel time. This method requires information such as an Origin Destination Matrix (OD Matrix), zoning, road network map, the length of each road and width of the road. Needed OD matrix for each year of analysis, and the future of OD matrix resulted from base year OD matrix multiplied by Growth Factor, it is useful as a means for validation.

Both of these methods when used to estimate the road maintenance fund needs in the future will certainly be different, whether the link based method will give a total cost of road maintenance less than NetworkBased approaches?.

\subsection{RESEARCH PURPOSES}

The purpose of this paper area:

A. Calculate traffic prediction in the link with linkbased approaches, calculate the estimated cost of road maintenance every year and find out the value of IRI at the end of the analysis.

B. Calculate traffic in link that is dynamically change due to influenced by IRI with Network-based approaches, calculate the estimated cost of maintenance of roads each year and find out value of IRI at the end of the analysis

C. Shows the difference in total cost of road maintenance needs, with the allocation of maintenance funds scripted $20 \%, \quad 40 \%$, $60 \%$ and $80 \%$ of the total annual cost of road maintenance. This scenario is applied to approaches Link based and Network based.

\subsection{SCOPE OF STUDY}

This study has several limitations that are used when analyzing, are:

A. Pavement type is a flexible pavement, and assumed the last maintenance done 2 years ago.

B. Growth Factor method of link-based and Network- based method is $3 \%$.

C. The IRI being used in the link is the average IRI

D. During the evaluation there is no addition of roads and increase capacity by adding lanes.

E. Drainse on the road network is considered in good condition

F. Traffic flow in the first year (2015) is the output of transport modeling with toolsEMME-4.

\subsection{RESEARCH METHODOLOGY}

In general, the research methodology is shown in Figure 2

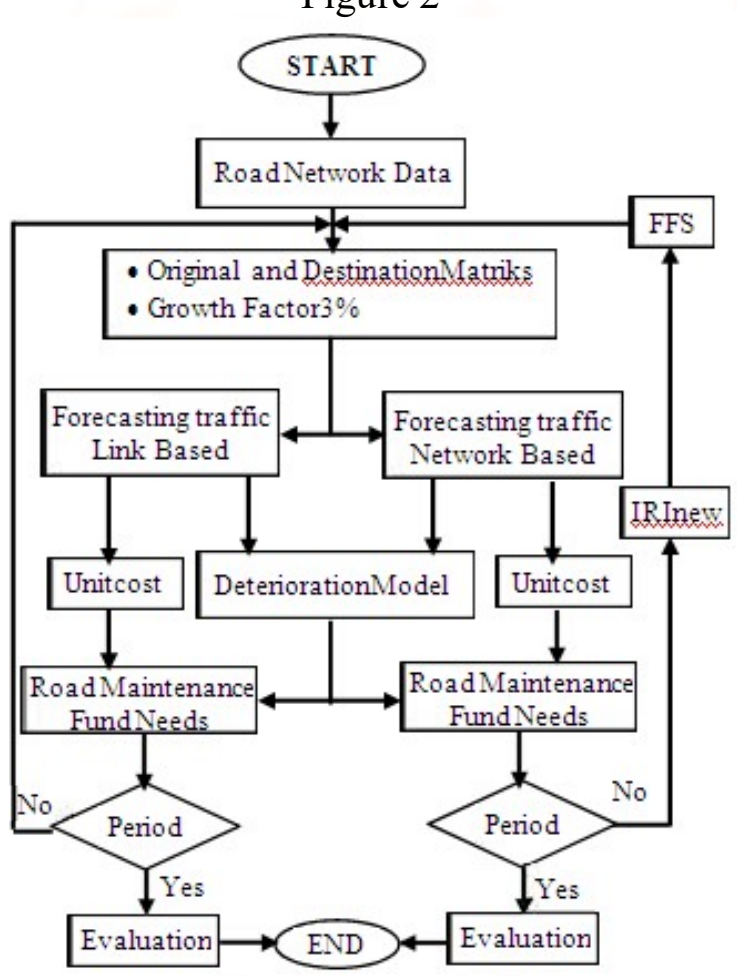

Figure2. Research methodology

\subsection{Road Net Work Data}

The road network data used in this study are the road network map in shp format and data link characteristics (length, width and the value of IRI).

\subsection{Estimates Traffic with Link Based Approaches}

In the first year, traffic is the output transport modeling with tools EMME 4. Forecasting traffic for next year, traffic on previous year multiplied by $3 \%$ as growth factor. The formula to estimate traffic in linkbase approach is [3]: 
Where:

$$
\text { A } \quad t_{r}=A b_{0}(1+) \ldots \ldots \ldots \ldots \ldots \ldots \ldots \ldots \ldots
$$

A $t_{\mathrm{r}}=$ number of vehicles per day on link I in year $\mathrm{n}$

A $\omega_{0}=$ number of vehicles per day on link I in the

$$
\begin{array}{ccc} 
& & \text { first year } \\
\mathrm{x} & & =\text { growth factor } \\
& \mathrm{n} & =\text { years }
\end{array}
$$

\subsection{Estimates Traffic with Link Based Approaches}

Forecasting traffic flow with network-based approaches using transport modeling tools EMME-4. It takes a information matrix Origin Destination (OD Matrix), growth factors OD Matrix, maps road network, road width, and the free flow speed on each road. Growth factors OD Matrix is $3 \%$. Tam in said that the transport in frastructure net work systems affect the movement of the system and vice versa [2]. Which differentiates it from link-based method compared to network-based is that the free flow speed is a function of IRI. While travel time is a function of free flow speed and travel time of the main things for road users to choose the sections that will be used. Roughness is unevenness of roads pavement surface, presented in a scale that describes unevenness of road surface. The International standard pavement roughness me asurement is called IRI, the unit is $\mathrm{m} /$ $\mathrm{km}$. The worse the road conditions would lead to reduced travel speed son roads. Sayers. et, al [3]. Recommend ed value of the speed of some IRI values. Dwilak so no Toto doing research to see correlation bet ween free flow speed and IRI in Java [4].

The correlation equation addressed in equation 2 :

$$
Y=0,0747 X^{-1}-3,4179 X+62,673
$$

\section{WHERE:}

$\mathrm{Y}=$ free flow speed $(\mathrm{km} / \mathrm{jam})$

$\mathrm{X}=$ average IRI in Link $(\mathrm{m} / \mathrm{km})$

\subsection{Road Deterioration Model}

There are two types of models that can be used to predict Road deterioration (RD) and Work Effects (WE) [5]:

\section{$>$ Model Absoulut \\ $>$ Model Incremental}

Absolute models predict pavement conditions at a particular point in time as a function of the independent variable, while the incremental models give the changing conditions of the initial conditions as a function of the independent variables. Both types of these models include the emperical models. Which means, these models are usually generated from the statistical analysis of the observations in the study of the trend of deterioration?

There are two types of de form at ion models dis tress, ie rutting and roughness. Rutting is defined as the accumulation of permanent deformation or not of overcoming traffic problem on the pavement, in the form of a tire tread groove within a certain time period [6]. There are four components of rutting, namely; initial densification, structural deformation, plastic deformation and wear form studded tires.

Roughness is defined as the deviation of the surface is completely flat with characteristics that affect the dynamic size vehicle, driving quality, load dynamics and surface drainage. Roughness model consists of several components, namely cracking, disintegration, deformation and maintenance.

In this study, the incremental roughness is calculated as a result of structural damage [7], the formula is:

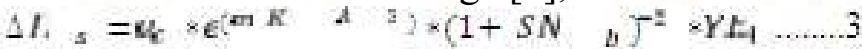

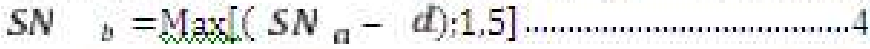

\section{WHERE:}

SNPKb = Adjustment Structural Numbers due to cracking at the end of year analysis

SNPa = Adjustment Structural Numbers due to cracking in the early years analysis

dSNPK = reduction in adjusted structural number of pavement due to cracking $\rightarrow$ its value is 3.6

$\Delta$ IRIs $=$ incremental change in roughness due to structural deterioration during the analysis year $(\mathrm{m} / \mathrm{km}$, IRI)

YE4 = annual number of equivalent standard axles (millions/lane)

Kgm $=$ calibration factor for environmental coefficient $\rightarrow$ its value is 7

AGE3 = pavement age since last overlay (rehabilitation), reconstruction or new construction (tahun)

a) $=$ roughness coefficient structural components $\rightarrow 134$

m = environmental coefficient $\rightarrow 0,025$

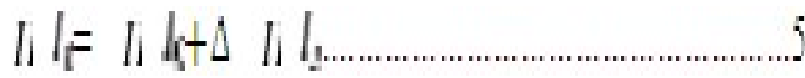




\section{WHERE:}

IRIt $=$ IRI at the end of year of analysis $(\mathrm{m} / \mathrm{km}, \mathrm{IRI})$ IRI0 $=$ IRI at early year of analysis $(\mathrm{m} / \mathrm{km}, \mathrm{IRI})$

\subsection{Equivalent Standard Axle Loads (Esal)}

This study has not valid ate the average weigh to feach class of vehicles passing through the road network of the study area. Therefore, using the Flexible Pavement Design Guidelines issued by the Ministry of Public Works Directorate General of Highways [8], where there are 8 classes of vehicles as shown Table1.

Tabel 1: Vehicle Damage Faktor (VDF) for each class group

\begin{tabular}{|c|l|c|}
\hline No. & \multicolumn{1}{|c|}{$\begin{array}{c}\text { Type of Class } \\
\text { VDF } \\
\text { Value }\end{array}$} \\
\hline 1 & Passenger vehicles (Class2) & 0.0001 \\
\hline 2 & Utility vehicles (Class 3\&4) & 0.0030 \\
\hline 3 & Small bus (Class5A) & 0.3000 \\
\hline 4 & Big Bus(Class5B) & 1.0000 \\
\hline 5 & small truck (Class6A) & 0.8000 \\
\hline 6 & big truck (Class6B) & 1.6000 \\
\hline 7 & Truck Trailers (Class 7A,7Bdan7C) & 7.6000 \\
\hline
\end{tabular}

\subsection{Annual Axle Loading}

Total weight of the axle for a year (ESAL) is calculated by multiplying the value of VDF with the number of vehicles passing each group on link.
$E A_{i}=\sum 365 * A l_{i} \times$
$V+10$

\section{WHERE:}

ESALij $=$ is the axle load during the i year in million ESAL for vehicle class $j$

$\mathbf{V D F} \mathbf{j}=$ Vehicle damage factor for vehicle class $\mathbf{j}$

AADT $_{i j}=$ Annual average daily traffic class $j$ during the I year

\subsection{Treatment Program}

Type of treatment is determined how much the damage, assessment parameter is the value of IRI. Table 2 showed parameters of road maintenance treatment based on the value of IRI.

\subsection{Unit Cost}

Table 3 shown the unit price of each maintenance activity per line width, Unit price is obtained from the Directorate General of Highways for the price of 2015,

\subsection{Scenario Allocated Road Maintenance Fund}

Road maintenance fund allocation scenarios for analysis with Link-Based and Network-Based approach are $20 \%, 40 \%, 60 \%$ and $80 \%$ of total road maintenance funds per each year. Due to limited funding, the roads that need to be addressed in the coming year chosen by considering the parameter value IRI, Cost, and AADT. Each segment is scored against all three parameters. Priority is determined based on the total scores of all three parameters.

Calculation of road Deterioration, selection of treatment and priority, and funding requirement of road maintenance against budgeting allocation scenario is using micro soft office-excel as a tool

\section{DATA AND ANALYSIS}

Research area located in the province of Bali, this province was chosen because of its territory in the form of an island, the refore the traffic flow continuously from outside the region can be eliminated.

Implementation of regional autonomy to the district/city level, then published the Law of the Republic of Indonesia No.38of2004, which is on the Way. There are settings that road authority; nationals roads, province's roads, county's road and city's road. Until now the technical information about the damage roads under authority of province, county's and city's is not as complete national's road, which is the authority of central government. Therefore, this research is still limited to the national road.

\subsection{National road network map and matrix origin Destin at ion Bali's}

This study uses a national road network map based on the Decree of the Minister of Public Works no. 248 / $\mathrm{KPTS} / \mathrm{M} / 2015$.ThenationalroadnetworkmaponBali is land in shp format is shown in Figure3.

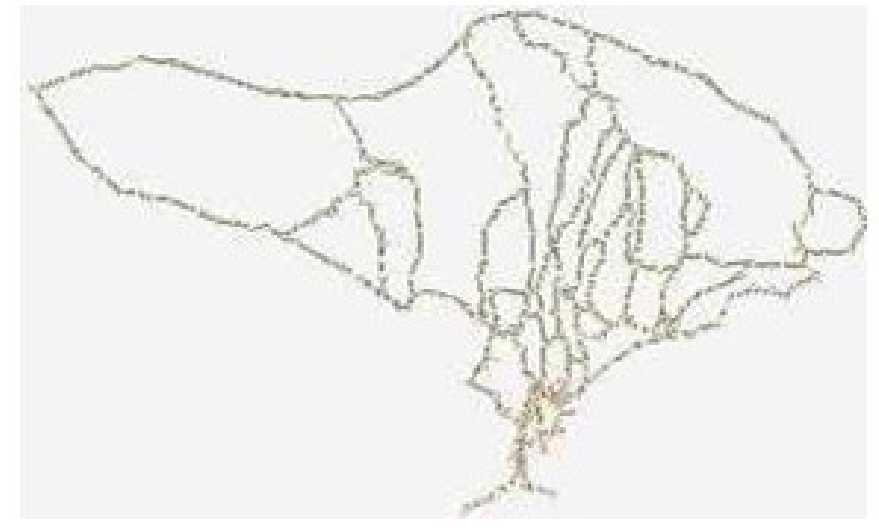

Figure3. National road network map in Bali Island 
The number of zones in the study area is divided into 33 zones. Zoning divided by district and sub-district administration. In downtown Denpasar and Bangli is divided into several zones based on the sub district.

Origin and destination distribution in the base year (2011) is shown in Table 4.

\subsection{Road characteristics and AADT at early year (2015)}

Characteristic of data used is length of road, average width of the road, average IRI, and AADT. This data is obtained from Agency that handles national road son Bali is land. Every 6 months the agency traffic measurement and national road conditions conducted. Traffic information on national roads is used to validate the movement model from 2011to2015. This paper does not discuss in more detail how to validate models and forecasting models with the EMME4 transport modeling program. Table $\mathbf{5}$ shown characteristic of national road on Bali is land.

\section{Analysis}

Analysis of road maintenance cost requirement with link based and network based approach for all national road net work in Bali is land. The analysis phase were traffic forecasting and then with variousfunding allocation scenarios calculated road maintenance fund need for each year.

\subsection{Traffic forecasting with link-based approaches}

Traffic forecast with Link-based approaches the way is multiply the growth factor to the existing traffic flow (seeeq.1). Soforthenext10years, the traffic fore casting are shown in Table 6. The traffic growth in each link is predicted $3 \%$ per year up to 2025 .

\subsection{Total road maintenance cost needs with link- based}

From the results of Table 6, following the pattern of the calculation described in Figure 2 are used to determine the needs of road maintenance funds from 2015 to 2025 (detail see Table 7).

Linkbased_20 and so on, meaning was analyzed by means of link based approach and allocation of cost maintenance every year is $20 \%$ of total cost maintenance needs of road network every year analysis. Simulation with multiple scenarios allocation of funds, it is known that the total cost of road maintenance needs until 2025 with an allocation of $20 \%$ of the total cost of road maintenance needs per year is Rp. 1.063.858.000.000. The condition of the road at the end of 2025 was deteriorating of the initial analysis (see Fig. 6). While if allocated funds amounting to $80 \%$ of the total requirement in each year, the total needs of the maintenance fund in 2015 until 2025 was Rp. 330.620.000.000,-. This number was not too significant losses than if allocated $60 \%$ of there quirement. This also applies to IRI, where allocations of $60 \%$ or $80 \%$ is not too large impact on improving the value of IRI.

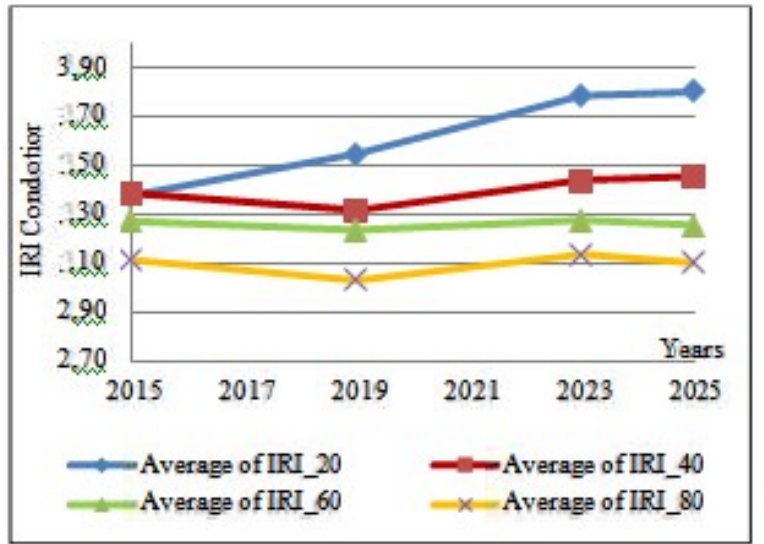

Figure4. IRI Condition per year by different allocation budget scenario with link-based analysis

Allocation road maintenance fund $20 \%$ of the total cost needs of each year, then at the end of 2025 the total cost of road maintenance bigger, other impact is the average value of IRI in the road network is greater than if the allocation of road maintenance funds increased to $40 \%$ of the total cost needs of each year. Figure 4 showed that there is a difference of each analysis at the end of 2025. This difference can be termed a san benefit for road managers. For road users, the advantage is travel speed undisrupted due to road damage, in the end there are savings in fuel consumption. The difference in total cost of road maintenance until 2025 in each year on the type of analysis is shown in Tabel 8. The differences can be a benefit for manager if allocation budget for maintenance bigger than it should be. Benefit from the allocation of $40 \%$ is the difference between the total cost of the allocation of $20 \%$ to the total cost of the allocation of $40 \%$, thus permanently for all scenarios allocation.

Table 8: Total road maintenance cost needs with link- based and benefit

\begin{tabular}{|c|c|c|}
\hline $\begin{array}{c}\text { Type of } \\
\text { Analysis }\end{array}$ & $\begin{array}{c}\text { Total Cost } \\
(\mathbf{2 0 1 5 - 2 0 2 5 )}\end{array}$ & Benefit \\
\hline Linkbased_20 & $1.063 .857,7$ & 0 \\
\hline Linkbased_40 & $528.738,2$ & $535.119,5$ \\
\hline Linkbased_60 & $373.709,0$ & $690.148,7$ \\
\hline Linkbased_80 & $330.619,5$ & $733.238,2$ \\
\hline
\end{tabular}




\subsection{Traffic forecast with network based}

In this approaches, the traffic flow forecasted does not based on growth traffic in link, but Origin Destination Matrix growth every year. Then, Matrix Origin Destination (OD Matrix) is charged on road network. Modeling of traffic flow on the road network using EMME-4, production by INRO Canada.

One of the outputs of the EMME-4 used are traffic flow in every link in each year. The next step is to calculate the number of vehicles by vehicle class and then calculated the total ESAL (see Table 1 and equation6).

Damage incremental in each link as a result of total ESAL, incremental damage in each segment as a result of total ESAL, calculated using equation 2, then at the end of $n$ year predicted value of IRI (see eq. 5) and the total funding of road maintenance e need sin yearn. Due to allocation of funds scripted always less than needed, then there is a process of evaluation of priority roads will be maintained, Once selected, anew IRI value used to calculate the free flow speed at the beginning of year $n+1$ using equation 2. This free flow speed information becomes the input current road network modeling with EMME-4 in the year $\mathrm{n}+$ 1 , and so on.

As a result, there are differences in total traffic flow in link that is calculated by link-based approaches and Network-based. Table 9 shown the differences, The differences around $5 \%$, traffic forecasting with linkbased higher than network-based.

\subsection{Total road maintenance cost needs with net work- based}

Following calculation pattern described in Figure 2, the road maintenance cost needs from 2015 to 2025 showed at Table 10.

Network based_20 and so on, meaning was analyzed by means of network based approach and allocation of cost maintenance every year is $20 \%$ of total cost maintenance needs of road network every year analysis. Simulation with multiple scenarios allocation of funds, it is known that the total cost of road maintenance needs until 2025 with an allocation of $20 \%$ of the total cost of road maintenance needs per year is Rp. 781.422 .000 .000 .

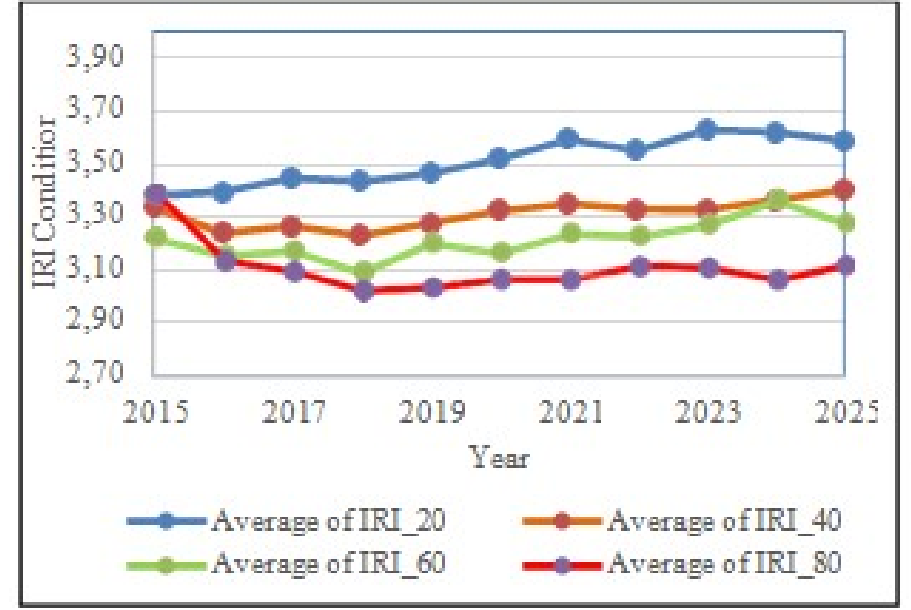

Figure5. IRI Condition per year by

Different allocation budget scenario With network-based analysis

Similar to the results of analysis with Link based approaches, Using Network-based approaches and the planned allocation of road maintenance fund $20 \%$ of the total requirement per year, the total cost of maintenance of the road at the end of 2025 is the biggest than if the funds allocated is greater than $20 \%$. It also gives the average value of IRI in the road network was getting worse. In Figure 5 is shown that the difference IRI condition in difference allocation scenarios maintenance of roads. Average of IRI_20 and so on, meaning average IRI per year for allocation budget $20 \%$ from maintenance needs, The difference in total cost of road maintenance until 2025 in each year on the type of analysis is shown in Table11.

Table 11: Total road maintenance cost needs with network-based and benefit

\begin{tabular}{|c|c|c|}
\hline Analysis Types & $\begin{array}{c}\text { Total Cost (Rp. } \\
\mathbf{1 . 0 0 0 . 0 0 0 , - )}\end{array}$ & $\begin{array}{c}\text { Benefit } \\
\text { (Rp.) }\end{array}$ \\
\hline Networkbased_20 & 781,422 & 0 \\
\hline Networkbased_40 & 521,417 & 260,005 \\
\hline Networkbased_60 & 432,214 & 349,208 \\
\hline Networkbased_80 & 324,832 & 456,590 \\
\hline
\end{tabular}

\section{DISCUSSION}

Link-based analysis method approaches and networkbased basically aimed is to try estimate of road maintenance cost needs in the future. Link-based would be very precisely and easy to implement by road asset managers to estimate the need for road maintenance funds in the short term at least for planning policy for funding up to 2 year. Data traffic in each segment needs to be updated annually in order to illustrate the impact of a road maintenance delays, 
implementation of these survey, it will add to the cost for road asset manager. These funds would be much better to increase road maintenance fund.

While network-based method that is modified to consider the influence of the IRI, it takes more effort, because managers need additional knowledge that is road transport modeling. But is more indicative the actual condition road user behavior.

Table 9 and table 10 indicated differences in estimation road maintenance costs needs in the future, which is analyzed with link-based and network-based approaches. With link-based approaches, road maintenance fund allocation plan by $20 \%$ of the total requirement road maintenance fund in 2015 , the total requirement for 10 year analysis (2015-2025) was $\mathrm{Rp}$. 1.063 .857 .700 .000 , this figure is very much compared to when traffic is expected in the future using a network- based approaches, as well as considering the IRI against the free flow speed in the next year, then total needs of road maintenance fund is Rp.781.422.000.000.
Table 12: The diferences Total Cost Maintenance Link based and Network based

\begin{tabular}{|c|c|c|c|}
\hline \multirow{3}{*}{$\begin{array}{l}\text { Alloc. } \\
\text { Plan. }\end{array}$} & \multirow{2}{*}{\multicolumn{2}{|c|}{$\begin{array}{l}\text { Total Maintenance Cost } \\
\text { (Fiscal Need) at The End } \\
2025 \text { (Rp. 1.000.000,-) } \\
\text { Analysis Types }\end{array}$}} & \multirow{3}{*}{ Difference } \\
\hline & & & \\
\hline & Link-based & $\begin{array}{c}\text { Network- } \\
\text { based }\end{array}$ & \\
\hline $20 \%$ & $1,063,857.71$ & 781,422 & $282,436.03$ \\
\hline $40 \%$ & $528,738.24$ & 521,417 & $7,321.48$ \\
\hline $60 \%$ & $373,709.04$ & 432,214 & $(58,505.07)$ \\
\hline $80 \%$ & $330,619.55$ & 324,832 & $5,788.04$ \\
\hline
\end{tabular}

Allocations plan $60 \%$ of the total road maintenance cost needs with link-based less than network-based. There are different sections that need to be maintained, due to differences traffic flow forecast. Consequently, there is differences roads maintenance programme. Example, randomly drawn average daily daily traffic (AADT) estimates using link based and network-based methods on 4 road segments in 2018, 2022 and 2025. Table 13 is shown that AADT linkbased increases constantly according to the growth assumption on the segment, while network-based can sometimes be higher than linked AADT estimates but in the coming year may be lower.

Table 13: AADT using network-based and link-based

\begin{tabular}{|c|c|c|c|}
\hline Years & Links & AADT by Networkbased & AADT by Link based \\
\hline \multirow{5}{*}{2018} & Sp.Cokroaminoto -Sp.Tohpati & 18.479 & 17.607 \\
\hline & Jln. A. Yani - Jln. S. Parman (Seririt) & 340 & 329 \\
\hline & Bts. Kota Gianyar -Sidan & 2.672 & 2.549 \\
\hline & Sp. Lap. Terbang (Dps) - TuguNgurah Ra & 35.976 & 34.273 \\
\hline & Jln. AstinaTimur(Gianyar) & 2.672 & 2.549 \\
\hline \multirow{5}{*}{2022} & Sp.Cokroaminoto - Sp.Tohpati (Jln. G.Su & 21.194 & 21.023 \\
\hline & Jln. A. Yani - Jln. S.Parman (Seririt) & 404 & 392 \\
\hline & Bts. Kota Gianyar -Sidan & 2.929 & 3.044 \\
\hline & Sp. Lap. Terbang (Dps) - TuguNgurahRa & 39.301 & 40.924 \\
\hline & Jln. AstinaTimur (Gianyar) & 2.790 & 3.044 \\
\hline
\end{tabular}

This difference can have an impact on the type of program on the road. See Table14, using networkbased methods, road number 33 are estimated to require preventive maintenance at year of 2022. While in the link base method, preventive maintenance is predicted need at road number 27 , while road number 33 required routine maintenance.

\section{CONCLUSION}

From the analysis, and network-based approach to link-based, it can be concluded some of the following: 1. Traffic Flow fore casting approaches link-based will always be increased even though the road is not repaired, it becomes different if carried out with a network-based approach.

2. Allocating $20 \%$ of the total road maintenance needs, at the end of 2025 if calculated by link based analysis will have the total cost $36 \%$ higher than network based analysis.

3. Allocating $20 \%$ of the total road maintenance needs in every year, at the end of 2025 will have the highest total cost compared to if the allocation of funds $40 \%, 60 \%$ and $80 \%$. 
International Journal of Trend in Scientific Research and Development (IJTSRD) | ISSN: 2456-647

4. At the end of 2025, the total cost of maintenance smaller when analyzed with a network-based approach, difference could reach $28 \%$ of the linkbased analysis.

\section{ACKNOWLEDGEMENTS}

The researchers would like to thank to rector of Mulawarman University and scholar for his support.

\section{REFERENCES}

1. Saedeh Fallah-Fini, "Optimizing highway maintenance operations", Dynamic considerations. System dynamic review, Vol. 26, No. 3. pp $216-238,2010$

2. Tamin O.Z, Planning and transport modeling: Penerbit ITB. Edisi 2. pp. 28,2000.

3. Sayers, "Guidelines for Conducting and Calibrating Road Roughness Measurements", World Bank technical paper number 46. pp. 72, 1986.
4. Dwilaksono Toto, "Pe model an Peren Canaan Komprihensip Pembangunan In frast rukturJalan (TinjauanJaringanJalan)",ThesisUI.pp.64,2002

5. Odoki (version 2). Manual Highway Development and Management 4. Vol. 4. pp. C1-8.

6. Odoki (version 2). Manual Highway Development and Management 4. Vol. 4. pp.C2-7

7. Odoki (version 2). Manual Highway Development and Management 4. Vol. 4. pp.C2-55

8. Ministry of Public Works Directorate General of Highways, Pavement design manual. pp. 19,2013

9. Badawi,"Studianalisispemelihanskenariopengemb anganangkutanumumkawasankota Denpasar danKabupatenBadungmenggunakanperangkatluna k EMME-4", ITB, 2013.

10. Ministry of Public Works Directorate General of Highways. (2014).

Table 2: Road maintenance programme consider IRI [10]

\begin{tabular}{|c|c|c|c|c|}
\hline $\begin{array}{c}\text { Name of } \\
\text { program }\end{array}$ & $\begin{array}{c}\text { Name of Sulb- } \\
\text { Programme }\end{array}$ & $\begin{array}{c}\text { Range of } \\
\text { IRI }\end{array}$ & IRI(n+1) & Treatment Details \\
\hline \multirow{5}{*}{$\begin{array}{c}\text { Routine } \\
\text { maintenance }\end{array}$} & Routine Maintenance(Pr) & $0-3.0$ & IRI min +0.5 & Maintenance of drainage systems \\
\cline { 2 - 5 } & $\begin{array}{c}\text { Conditions Routine } \\
\text { Maintenance (Prk) }\end{array}$ & $3.0-4$ & IRI min - 0.5 & $\begin{array}{c}\text { maintenance of road shoulders; } \\
\text { vegetation clerance }\end{array}$ \\
\cline { 2 - 5 } & $\begin{array}{c}\text { Preventif maintenance } \\
(\text { Pp) }\end{array}$ & $4.0-6.0$ & IRI min - 0.5 & $\begin{array}{c}\text { Patching, sealing for surface crack, } \\
\text { reformation of shoulder. } \\
\text { road maintenance equipment }\end{array}$ \\
\cline { 2 - 5 } & $\begin{array}{c}\text { Minor rehabilitation } \\
(\mathrm{RMn})\end{array}$ & $6.0-8.0$ & to3.0 & Non-structural overlay \\
\hline \multirow{2}{*}{ Improvement } & $\begin{array}{c}\text { Major rehabilitation } \\
(\mathrm{Rmy})\end{array}$ & $8.0-12.0$ & to 3.0 & Structural overlay and repair \\
\hline
\end{tabular}

Table 3: Unit cost for each treatment

\begin{tabular}{|c|c|c|c|}
\hline Nu. & Description & Unit & Cost/km(Rp.1000) \\
\hline & Routine maintenance and Conditions (IRI 0 - 4) & & \\
\hline & Pav. width upto 4.5 $\mathrm{m}$ and shoulder 2x1m & $\mathrm{Km}$ & 36,785 \\
\hline I & Pav. width upto 5 m and shoulder 2x1m & $\mathrm{Km}$ & 37,488 \\
\hline & Pav. width upto 6 $\mathrm{m}$ and shoulder 2x1.5m & $\mathrm{Km}$ & 40,866 \\
\hline & Pav. width upto 7 m and shoulder 2x2m & $\mathrm{Km}$ & 44,244 \\
\hline & Pav. width upto s/d 14 m and shoulder 2x2m & $\mathrm{Km}$ & 54,987 \\
\hline & Preventif maintenance (IRI 4 - 6) & & \\
\hline & Pav. width upto 4.5 m and shoulder 2x1 m & $\mathrm{Km}$ & 468,413 \\
\hline II & Pav. width upto 5 m and shoulder 2x1 m & $\mathrm{Km}$ & 510,385 \\
\hline & Pav. width upto 6 m and shoulder 2x1.5 m & $\mathrm{Km}$ & 607,365 \\
\hline & Pav. width upto 7 $\mathrm{m}$ and shoulder 2x2 m & $\mathrm{Km}$ & 694,582 \\
\hline & Pav. width upto 14 $\mathrm{m}$ and shoulder 2x2 m & $\mathrm{Km}$ & $1,364,499$ \\
\hline
\end{tabular}


International Journal of Trend in Scientific Research and Development (IJTSRD) | ISSN: 2456-647

\begin{tabular}{|c|c|c|c|}
\hline & Minor Rehabilitation (IRI 6.0 - 8.0) & & \\
\hline & Pav. width upto $4.5 \mathrm{~m}$ and shoulder $2 \times 1 \mathrm{~m}$ & $\mathrm{Km}$ & 780,689 \\
\hline & Pav. width upto $5 \mathrm{~m}$ and shoulder $2 \times 1 \mathrm{~m}$ & $\mathrm{Km}$ & 850,641 \\
\hline \multirow[t]{10}{*}{ III } & Pav. width upto $6 \mathrm{~m}$ and shoulder $2 \times 1.5 \mathrm{~m}$ & $\mathrm{Km}$ & $1,012,275$ \\
\hline & Pav. width upto $7 \mathrm{~m}$ and shoulder $2 \times 2 \mathrm{~m}$ & $\mathrm{Km}$ & $1,157,637$ \\
\hline & Pav. width upto $14 \mathrm{~m}$ and shoulder $2 \times 2 \mathrm{~m}$ & $\mathrm{Km}$ & $2,274,165$ \\
\hline & Improvement & & \\
\hline & Major Rehabilitation (IRI 8.0 - 12.0) & & \\
\hline & Pav. width upto $4.5 \mathrm{~m}$ and shoulder $2 \times 1 \mathrm{~m}$ & $\mathrm{Km}$ & $2,431,018$ \\
\hline & Pav. width upto $5 \mathrm{~m}$ and shoulder $2 \times 1 \mathrm{~m}$ & $\mathrm{Km}$ & $2,675,174$ \\
\hline & Pav. width upto $6 \mathrm{~m}$ and shoulder $2 \times 1.5 \mathrm{~m}$ & $\mathrm{Km}$ & $3,220,695$ \\
\hline & Pav. width upto $7 \mathrm{~m}$ and shoulder $2 \times 2 \mathrm{~m}$ & $\mathrm{Km}$ & $3,757,813$ \\
\hline & Pav. width upto $14 \mathrm{~m}$ and shoulder $2 \times 2 \mathrm{~m}$ & $\mathrm{Km}$ & $7,310,172$ \\
\hline \multirow[t]{6}{*}{ IV } & Reconstruction (IRI > 12) & & \\
\hline & Pav. width upto $4.5 \mathrm{~m}$ and shoulder $2 \times 1 \mathrm{~m}$ & $\mathrm{Km}$ & $3,006,939$ \\
\hline & Pav. width upto $5 \mathrm{~m}$ and shoulder $2 \times 1 \mathrm{~m}$ & $\mathrm{Km}$ & $3,314,358$ \\
\hline & Pav. width upto $6 \mathrm{~m}$ and shoulder $2 \times 1.5 \mathrm{~m}$ & $\mathrm{Km}$ & $4,279,337$ \\
\hline & Pav. width upto $7 \mathrm{~m}$ and shoulder $2 \times 2 \mathrm{~m}$ & $\mathrm{Km}$ & $4,993,006$ \\
\hline & Pav. width upto $14 \mathrm{~m}$ and shoulder $2 \times 2 \mathrm{~m}$ & $\mathrm{Km}$ & $9,774,596$ \\
\hline
\end{tabular}

Table4. Original and destination matrix on base year 2011[9]

\begin{tabular}{|c|c|c|c|c|c|c|c|c|c|c|c|c|c|c|c|c|c|c|c|c|c|c|c|c|c|c|c|c|c|c|c|c|c|c|}
\hline \multirow{2}{*}{$\begin{array}{l}\mathbf{N} \\
\mathbf{0}\end{array}$} & \multirow[b]{2}{*}{ Zona } & \multicolumn{33}{|c|}{ Zona } \\
\hline & & 1 & 2 & 3 & 4 & 5 & 6 & 7 & 8 & 9 & $\begin{array}{l}1 \\
0\end{array}$ & $\begin{array}{l}1 \\
1\end{array}$ & $\begin{array}{l}1 \\
2\end{array}$ & $\begin{array}{l}1 \\
3\end{array}$ & $\begin{array}{l}1 \\
4\end{array}$ & $\begin{array}{l}1 \\
5\end{array}$ & $\begin{array}{l}1 \\
6\end{array}$ & $\begin{array}{l}1 \\
7\end{array}$ & $\begin{array}{l}1 \\
8\end{array}$ & $\begin{array}{l}1 \\
9\end{array}$ & \begin{tabular}{l|}
2 \\
0
\end{tabular} & \begin{tabular}{l|}
2 \\
1
\end{tabular} & $\begin{array}{l}2 \\
2\end{array}$ & $\begin{array}{l}2 \\
3\end{array}$ & $\begin{array}{l}2 \\
4\end{array}$ & $\begin{array}{l}2 \\
5\end{array}$ & $\begin{array}{l}2 \\
6\end{array}$ & $\begin{array}{l}2 \\
7\end{array}$ & $\begin{array}{l}2 \\
8\end{array}$ & $\begin{array}{l}2 \\
9\end{array}$ & $\begin{array}{l}3 \\
0\end{array}$ & $\begin{array}{l}3 \\
1\end{array}$ & $\begin{array}{l}3 \\
2\end{array}$ & $\begin{array}{l}3 \\
3\end{array}$ \\
\hline 1 & Pecatu & 0 & $\begin{array}{l}5 \\
0\end{array}$ & $\begin{array}{l}1 \\
1 \\
0\end{array}$ & $\begin{array}{l}2 \\
0\end{array}$ & $\begin{array}{l}5 \\
0\end{array}$ & $\begin{array}{l}1 \\
0\end{array}$ & 0 & 0 & 0 & $\begin{array}{l}1 \\
0\end{array}$ & 0 & $\begin{array}{l}7 \\
0\end{array}$ & 0 & $\begin{array}{l}4 \\
0\end{array}$ & $\begin{array}{l}1 \\
0\end{array}$ & $\begin{array}{l}3 \\
0\end{array}$ & $\begin{array}{l}3 \\
0\end{array}$ & $\begin{array}{l}3 \\
0\end{array}$ & $\begin{array}{l}3 \\
0\end{array}$ & $\begin{array}{l}1 \\
0\end{array}$ & 0 & 0 & $\begin{array}{l}4 \\
0\end{array}$ & $\begin{array}{l}1 \\
0\end{array}$ & $\begin{array}{l}6 \\
0\end{array}$ & $\begin{array}{l}5 \\
0\end{array}$ & $\begin{array}{l}2 \\
9 \\
0\end{array}$ & $\begin{array}{l}3 \\
0\end{array}$ & $\begin{array}{l}4 \\
0\end{array}$ & 0 & 0 & 0 & $\begin{array}{l}3 \\
0\end{array}$ \\
\hline 2 & $\begin{array}{l}\text { Tanju } \\
\text { ngBen } \\
\text { oa }\end{array}$ & $\begin{array}{l}3 \\
0\end{array}$ & 0 & $\begin{array}{l}1 \\
0 \\
0\end{array}$ & $\begin{array}{l}4 \\
0\end{array}$ & $\begin{array}{l}1 \\
3 \\
0\end{array}$ & $\begin{array}{l}1 \\
0\end{array}$ & 0 & 0 & $\begin{array}{l}2 \\
0\end{array}$ & $\begin{array}{l}1 \\
0\end{array}$ & 0 & $\begin{array}{l}1 \\
8 \\
0\end{array}$ & $\begin{array}{l}3 \\
0\end{array}$ & $\begin{array}{l}6 \\
0\end{array}$ & 0 & $\begin{array}{l}1 \\
0\end{array}$ & $\begin{array}{l}1 \\
3 \\
0\end{array}$ & $\begin{array}{l}8 \\
0\end{array}$ & $\begin{array}{l}1 \\
5 \\
0\end{array}$ & $\begin{array}{l}1 \\
0\end{array}$ & $\begin{array}{l}1 \\
0\end{array}$ & 0 & $\begin{array}{l}9 \\
0\end{array}$ & $\begin{array}{l}1 \\
0\end{array}$ & $\begin{array}{l}5 \\
0\end{array}$ & $\begin{array}{l}1 \\
8 \\
0\end{array}$ & $\begin{array}{l}2 \\
5 \\
0\end{array}$ & 0 & $\begin{array}{l}5 \\
0\end{array}$ & $\begin{array}{l}1 \\
0\end{array}$ & 0 & 0 & $\begin{array}{l}5 \\
0\end{array}$ \\
\hline 3 & $\begin{array}{l}\text { Jim } \\
\text { baran }\end{array}$ & $\begin{array}{l}1 \\
3 \\
0 \\
\end{array}$ & $\begin{array}{l}3 \\
0 \\
0 \\
\end{array}$ & 0 & $\begin{array}{l}4 \\
0\end{array}$ & $\begin{array}{l}2 \\
7 \\
0\end{array}$ & $\begin{array}{l}1 \\
0\end{array}$ & 0 & $\begin{array}{l}1 \\
0\end{array}$ & $\begin{array}{l}1 \\
0\end{array}$ & $\begin{array}{l}5 \\
0\end{array}$ & 0 & $\begin{array}{l}2 \\
6 \\
0 \\
\end{array}$ & $\begin{array}{l}2 \\
0\end{array}$ & $\begin{array}{l}7 \\
0\end{array}$ & $\begin{array}{l}1 \\
0\end{array}$ & $\begin{array}{l}6 \\
0\end{array}$ & $\begin{array}{l}1 \\
0 \\
0 \\
\end{array}$ & $\begin{array}{l}1 \\
7 \\
0 \\
\end{array}$ & $\begin{array}{l}2 \\
6 \\
0 \\
\end{array}$ & $\begin{array}{l}4 \\
0\end{array}$ & $\begin{array}{l}3 \\
0\end{array}$ & 0 & $\begin{array}{l}5 \\
0\end{array}$ & $\begin{array}{l}3 \\
0\end{array}$ & $\begin{array}{l}1 \\
5 \\
0 \\
\end{array}$ & $\begin{array}{l}2 \\
8 \\
0 \\
\end{array}$ & \begin{tabular}{|l|}
2 \\
0 \\
0 \\
\end{tabular} & $\begin{array}{l}3 \\
0\end{array}$ & $\begin{array}{l}7 \\
0\end{array}$ & $\begin{array}{l}1 \\
0\end{array}$ & $\begin{array}{l}3 \\
0\end{array}$ & 0 & $\begin{array}{l}1 \\
0\end{array}$ \\
\hline 4 & Tuban & $\begin{array}{l}3 \\
0\end{array}$ & $\begin{array}{l}1 \\
5 \\
0\end{array}$ & $\begin{array}{l}7 \\
0\end{array}$ & 0 & $\begin{array}{l}7 \\
0\end{array}$ & 0 & 0 & 0 & 0 & 0 & 0 & $\begin{array}{l}1 \\
3 \\
0\end{array}$ & 0 & $\begin{array}{l}9 \\
0\end{array}$ & $\begin{array}{l}2 \\
0\end{array}$ & $\begin{array}{l}8 \\
0\end{array}$ & $\begin{array}{l}1 \\
7 \\
0\end{array}$ & $\begin{array}{l}5 \\
0\end{array}$ & $\begin{array}{l}1 \\
1 \\
0 \\
\end{array}$ & $\begin{array}{l}2 \\
0\end{array}$ & $\begin{array}{l}1 \\
0\end{array}$ & 0 & $\begin{array}{l}2 \\
0\end{array}$ & 0 & $\begin{array}{l}4 \\
0\end{array}$ & $\begin{array}{l}1 \\
6 \\
0 \\
\end{array}$ & \begin{tabular}{|l|}
1 \\
1 \\
0 \\
\end{tabular} & $\begin{array}{l}2 \\
0\end{array}$ & 0 & 0 & 0 & 0 & 0 \\
\hline 5 & Kuta & $\begin{array}{l}3 \\
0 \\
0 \\
\end{array}$ & $\begin{array}{l}5 \\
8 \\
0 \\
\end{array}$ & $\begin{array}{l}3 \\
9 \\
0\end{array}$ & $\begin{array}{l}3 \\
0\end{array}$ & 0 & $\begin{array}{l}1 \\
0\end{array}$ & 0 & 0 & 0 & 0 & 0 & $\begin{array}{l}3 \\
7 \\
0\end{array}$ & 0 & $\begin{array}{l}3 \\
0\end{array}$ & 0 & $\begin{array}{l}4 \\
0\end{array}$ & $\begin{array}{l}8 \\
0\end{array}$ & $\begin{array}{l}1 \\
0\end{array}$ & $\begin{array}{l}1 \\
7 \\
0\end{array}$ & $\begin{array}{l}7 \\
0\end{array}$ & $\begin{array}{l}2 \\
0\end{array}$ & 0 & $\begin{array}{l}1 \\
0\end{array}$ & $\begin{array}{l}3 \\
0\end{array}$ & $\begin{array}{l}1 \\
7 \\
0\end{array}$ & $\begin{array}{l}1 \\
5 \\
0 \\
\end{array}$ & \begin{tabular}{|l|}
1 \\
3 \\
0 \\
\end{tabular} & $\begin{array}{l}1 \\
0\end{array}$ & $\begin{array}{l}7 \\
0\end{array}$ & $\begin{array}{l}1 \\
0\end{array}$ & 0 & 0 & $\begin{array}{l}4 \\
0\end{array}$ \\
\hline 6 & $\begin{array}{l}\text { Kerob } \\
\text { okan }\end{array}$ & $\begin{array}{l}3 \\
0\end{array}$ & $\begin{array}{l}5 \\
0\end{array}$ & $\begin{array}{l}8 \\
0 \\
\end{array}$ & 1 & $\begin{array}{l}5 \\
0\end{array}$ & 0 & 0 & 0 & 0 & 0 & 0 & 0 & 0 & 0 & 0 & 0 & $\begin{array}{l}1 \\
0\end{array}$ & 0 & 0 & 0 & 0 & 0 & 0 & 0 & 0 & 0 & 0 & 0 & 0 & 0 & 0 & 0 & 0 \\
\hline 7 & $\begin{array}{l}\text { Kerob } \\
\text { okan } \\
\text { Kelod }\end{array}$ & 0 & 0 & $\begin{array}{l}1 \\
0\end{array}$ & 0 & 0 & 0 & 0 & 0 & 0 & 0 & 0 & 0 & 0 & 0 & 0 & 0 & 0 & 0 & 0 & 0 & 0 & 0 & 0 & 0 & 0 & 0 & 0 & 0 & 0 & 0 & 0 & 0 & 0 \\
\hline 8 & $\begin{array}{l}\text { Cangg } \\
\mathrm{u}\end{array}$ & $\begin{array}{l}3 \\
0\end{array}$ & $\begin{array}{l}1 \\
0\end{array}$ & $\begin{array}{l}1 \\
0\end{array}$ & 0 & $\begin{array}{l}1 \\
0\end{array}$ & 0 & 0 & 0 & 0 & 0 & 0 & 0 & 0 & 0 & 0 & 0 & 0 & 0 & $\begin{array}{l}1 \\
0\end{array}$ & 0 & 0 & 0 & 0 & 0 & 0 & 0 & \begin{tabular}{|l|}
2 \\
0
\end{tabular} & 0 & 0 & 0 & 0 & 0 & 0 \\
\hline 9 & $\begin{array}{l}\text { Dalun } \\
\mathrm{g}\end{array}$ & $\begin{array}{l}1 \\
2 \\
0\end{array}$ & $\begin{array}{l}1 \\
1 \\
0\end{array}$ & $\begin{array}{l}7 \\
0\end{array}$ & $\begin{array}{l}1 \\
0\end{array}$ & $\begin{array}{l}1 \\
0\end{array}$ & 0 & 0 & 0 & 0 & 0 & 0 & 0 & 0 & 0 & 0 & 0 & 0 & 0 & 0 & 0 & 0 & 0 & 0 & 0 & 0 & 0 & 0 & 0 & 0 & 0 & 0 & 0 & 0 \\
\hline $\begin{array}{l}1 \\
0\end{array}$ & $\begin{array}{l}\text { Meng } \\
\text { wi }\end{array}$ & $\begin{array}{l}1 \\
2 \\
0\end{array}$ & $\begin{array}{l}1 \\
8 \\
0\end{array}$ & $\begin{array}{l}9 \\
0\end{array}$ & $\begin{array}{l}8 \\
0\end{array}$ & $\begin{array}{l}4 \\
0\end{array}$ & 0 & 0 & 0 & $\begin{array}{l}1 \\
0\end{array}$ & 0 & 0 & 0 & 0 & 0 & 0 & 0 & 0 & 0 & 0 & 0 & 0 & 0 & 0 & 0 & 0 & 0 & 0 & 0 & 0 & 0 & 0 & 0 & 0 \\
\hline $\begin{array}{l}1 \\
1 \\
\end{array}$ & $\begin{array}{l}\text { Abian } \\
\text { sem al }\end{array}$ & $\begin{array}{l}2 \\
0 \\
\end{array}$ & $\begin{array}{l}2 \\
0 \\
\end{array}$ & \begin{tabular}{|l|}
2 \\
0 \\
\end{tabular} & 0 & $\begin{array}{l}2 \\
0 \\
\end{array}$ & 0 & 0 & 0 & 0 & 0 & 0 & 0 & 0 & 0 & 0 & 0 & 0 & 0 & 0 & 0 & 0 & 0 & 0 & 0 & 0 & 0 & 0 & 0 & 0 & 0 & 0 & 0 & 0 \\
\hline $\begin{array}{l}1 \\
2\end{array}$ & $\begin{array}{l}\text { Dangi } \\
\text { npuri }\end{array}$ & $\begin{array}{l}1 \\
8 \\
0\end{array}$ & $\begin{array}{l}5 \\
5 \\
0\end{array}$ & \begin{tabular}{|l}
6 \\
7 \\
0
\end{tabular} & $\begin{array}{l}3 \\
9 \\
0\end{array}$ & $\begin{array}{l}8 \\
8 \\
0\end{array}$ & 0 & $\begin{array}{l}1 \\
0\end{array}$ & 0 & 0 & 0 & 0 & 0 & $\begin{array}{l}1 \\
0\end{array}$ & $\begin{array}{l}1 \\
0\end{array}$ & 0 & $\begin{array}{l}2 \\
0\end{array}$ & $\begin{array}{l}4 \\
0\end{array}$ & $\begin{array}{l}2 \\
0\end{array}$ & $\begin{array}{l}1 \\
6 \\
0\end{array}$ & $\begin{array}{l}1 \\
0\end{array}$ & 0 & $\begin{array}{l}1 \\
0\end{array}$ & 0 & 0 & 0 & $\begin{array}{l}1 \\
0\end{array}$ & $\begin{array}{l}1 \\
0\end{array}$ & $\begin{array}{l}1 \\
0\end{array}$ & $\begin{array}{l}1 \\
0\end{array}$ & 0 & $\begin{array}{l}1 \\
0\end{array}$ & $\begin{array}{l}1 \\
0\end{array}$ & 0 \\
\hline $\begin{array}{l}1 \\
3 \\
\end{array}$ & $\begin{array}{l}\text { Sum } \\
\text { erta }\end{array}$ & 0 & $\begin{array}{l}2 \\
0 \\
\end{array}$ & \begin{tabular}{|l|}
3 \\
0 \\
\end{tabular} & $\begin{array}{l}1 \\
0 \\
\end{array}$ & $\begin{array}{l}3 \\
0 \\
\end{array}$ & 0 & 0 & $\begin{array}{l}1 \\
0 \\
\end{array}$ & 0 & 0 & 0 & 0 & 0 & 0 & 0 & 0 & $\begin{array}{l}2 \\
0 \\
\end{array}$ & 0 & $\begin{array}{l}1 \\
0 \\
\end{array}$ & 0 & 0 & 0 & 0 & 0 & 0 & 0 & 0 & 0 & 0 & 0 & 0 & 0 & 0 \\
\hline $\begin{array}{l}1 \\
4\end{array}$ & $\begin{array}{l}\text { Kesim } \\
\text { an }\end{array}$ & $\begin{array}{l}1 \\
0 \\
0\end{array}$ & $\begin{array}{l}6 \\
0\end{array}$ & $\begin{array}{l}4 \\
0\end{array}$ & 0 & $\begin{array}{l}2 \\
0\end{array}$ & 0 & 0 & 0 & 0 & 0 & 0 & 0 & 0 & 0 & 0 & 0 & 0 & 0 & $\begin{array}{l}1 \\
0\end{array}$ & 0 & 0 & 0 & 0 & 0 & $\begin{array}{l}1 \\
0\end{array}$ & 0 & 0 & 0 & 0 & 0 & 0 & 0 & 0 \\
\hline 1 & Penati & 4 & 3 & 3 & 0 & 1 & 0 & 0 & 0 & 0 & 0 & 0 & 0 & 0 & 0 & 0 & 0 & 0 & 0 & 0 & 0 & 0 & 0 & 0 & 0 & 0 & 0 & 0 & 0 & 0 & \begin{tabular}{|l|}
0 \\
\end{tabular} & 0 & 0 & 0 \\
\hline
\end{tabular}


International Journal of Trend in Scientific Research and Development (IJTSRD) | ISSN: 2456-647

\begin{tabular}{|c|c|c|c|c|c|c|c|c|c|c|c|c|c|c|c|c|c|c|c|c|c|c|c|c|c|c|c|c|c|c|c|c|c|c|}
\hline 5 & $\mathrm{~h}$ & 0 & 0 & 0 & & 0 & & & & & & & & & & & & & & & & & & & & & & & & & & & & \\
\hline $\begin{array}{l}1 \\
6\end{array}$ & $\begin{array}{l}\text { Pedun } \\
\text { gan }\end{array}$ & $\begin{array}{l}8 \\
0\end{array}$ & $\begin{array}{l}9 \\
0\end{array}$ & $\begin{array}{l}9 \\
0\end{array}$ & $\begin{array}{l}1 \\
0\end{array}$ & $\begin{array}{l}3 \\
0\end{array}$ & 0 & 0 & 0 & 0 & 0 & 0 & $\begin{array}{l}7 \\
0\end{array}$ & 0 & $\begin{array}{l}1 \\
0\end{array}$ & $\begin{array}{l}1 \\
0\end{array}$ & 0 & $\begin{array}{l}3 \\
0\end{array}$ & $\begin{array}{l}5 \\
0\end{array}$ & $\begin{array}{l}1 \\
4 \\
0\end{array}$ & 0 & 0 & 0 & $\begin{array}{l}3 \\
0\end{array}$ & 0 & $\begin{array}{l}1 \\
0\end{array}$ & $\begin{array}{l}1 \\
0\end{array}$ & 0 & 0 & $\begin{array}{l}2 \\
0\end{array}$ & $\begin{array}{l}1 \\
0\end{array}$ & 0 & 0 & 0 \\
\hline $\begin{array}{l}1 \\
7\end{array}$ & $\begin{array}{l}\text { Seseta } \\
\mathrm{n}\end{array}$ & $\begin{array}{l}9 \\
0\end{array}$ & $\begin{array}{l}1 \\
9 \\
0\end{array}$ & $\begin{array}{l}1 \\
9 \\
0\end{array}$ & $\begin{array}{l}3 \\
0\end{array}$ & $\begin{array}{l}8 \\
0\end{array}$ & 0 & $\begin{array}{l}1 \\
0\end{array}$ & 0 & 0 & 0 & 0 & $\begin{array}{l}3 \\
0\end{array}$ & 0 & 0 & 0 & $\begin{array}{l}7 \\
0\end{array}$ & 0 & $\begin{array}{l}4 \\
0\end{array}$ & $\begin{array}{l}9 \\
0\end{array}$ & 0 & $\begin{array}{l}1 \\
0\end{array}$ & 0 & $\begin{array}{l}3 \\
0\end{array}$ & $\begin{array}{l}1 \\
0\end{array}$ & $\begin{array}{l}1 \\
0\end{array}$ & $\begin{array}{l}4 \\
0\end{array}$ & $\begin{array}{l}4 \\
0\end{array}$ & $\begin{array}{l}1 \\
0\end{array}$ & 0 & 0 & 0 & $\begin{array}{l}1 \\
0\end{array}$ & $\begin{array}{l}1 \\
0\end{array}$ \\
\hline $\begin{array}{l}1 \\
8\end{array}$ & $\begin{array}{l}\text { Sidaka } \\
\text { rya }\end{array}$ & $\begin{array}{l}9 \\
0\end{array}$ & $\begin{array}{l}1 \\
3 \\
0 \\
\end{array}$ & $\begin{array}{l}2 \\
1 \\
0 \\
\end{array}$ & $\begin{array}{l}1 \\
0 \\
0 \\
\end{array}$ & $\begin{array}{l}7 \\
0\end{array}$ & 0 & 0 & 0 & 0 & 0 & $\begin{array}{l}1 \\
0\end{array}$ & 0 & 0 & 0 & 0 & $\begin{array}{l}5 \\
0\end{array}$ & $\begin{array}{l}7 \\
0\end{array}$ & 0 & $\begin{array}{l}8 \\
0\end{array}$ & $\begin{array}{l}2 \\
0\end{array}$ & 0 & 0 & $\begin{array}{l}1 \\
0\end{array}$ & 0 & $\begin{array}{l}2 \\
0\end{array}$ & $\begin{array}{l}1 \\
0\end{array}$ & $\begin{array}{l}4 \\
0\end{array}$ & 0 & 0 & $\begin{array}{l}2 \\
0\end{array}$ & 0 & 0 & 0 \\
\hline $\begin{array}{l}1 \\
9\end{array}$ & Sanur & $\begin{array}{l}1 \\
8 \\
0 \\
\end{array}$ & $\begin{array}{l}2 \\
3 \\
0 \\
\end{array}$ & $\begin{array}{l}2 \\
8 \\
0 \\
\end{array}$ & $\begin{array}{l}1 \\
6 \\
0 \\
\end{array}$ & $\begin{array}{l}2 \\
8 \\
0 \\
\end{array}$ & 0 & 0 & 0 & 0 & 0 & 0 & $\begin{array}{l}2 \\
0\end{array}$ & 0 & 0 & 0 & $\begin{array}{l}1 \\
0\end{array}$ & $\begin{array}{l}5 \\
0\end{array}$ & $\begin{array}{l}4 \\
0\end{array}$ & 0 & 0 & 0 & 0 & $\begin{array}{l}1 \\
0\end{array}$ & 0 & $\begin{array}{l}1 \\
0\end{array}$ & $\begin{array}{l}2 \\
0\end{array}$ & $\begin{array}{l}1 \\
0\end{array}$ & 0 & 0 & 0 & 0 & 0 & 0 \\
\hline $\begin{array}{l}2 \\
0\end{array}$ & $\begin{array}{l}\text { Pemo } \\
\text { ngan }\end{array}$ & $\begin{array}{l}6 \\
0\end{array}$ & $\begin{array}{l}1 \\
2 \\
0 \\
\end{array}$ & $\begin{array}{l}9 \\
0\end{array}$ & $\begin{array}{l}3 \\
0\end{array}$ & $\begin{array}{l}3 \\
0\end{array}$ & 0 & 0 & 0 & 0 & 0 & 0 & $\begin{array}{l}1 \\
0\end{array}$ & 0 & $\begin{array}{l}1 \\
0\end{array}$ & $\begin{array}{l}1 \\
0\end{array}$ & 0 & $\begin{array}{l}3 \\
0\end{array}$ & $\begin{array}{l}3 \\
0\end{array}$ & $\begin{array}{l}1 \\
2 \\
0 \\
\end{array}$ & 0 & 0 & $\begin{array}{l}1 \\
0\end{array}$ & 0 & 0 & 0 & $\begin{array}{l}1 \\
0\end{array}$ & $\begin{array}{l}5 \\
0\end{array}$ & $\begin{array}{l}1 \\
0\end{array}$ & 0 & 0 & 0 & 0 & $\begin{array}{l}2 \\
0\end{array}$ \\
\hline $\begin{array}{l}2 \\
1 \\
\end{array}$ & Ubung & $\begin{array}{l}4 \\
0 \\
\end{array}$ & $\begin{array}{l}7 \\
0 \\
\end{array}$ & $\begin{array}{l}7 \\
0 \\
\end{array}$ & $\begin{array}{l}1 \\
0\end{array}$ & $\begin{array}{l}6 \\
0\end{array}$ & 0 & 0 & 0 & 0 & 0 & 0 & 0 & 0 & 0 & 0 & 0 & 0 & 0 & $\begin{array}{l}1 \\
0 \\
\end{array}$ & 0 & 0 & 0 & 0 & 0 & 0 & 0 & 0 & 0 & 0 & 0 & 0 & 0 & 0 \\
\hline $\begin{array}{l}2 \\
2 \\
\end{array}$ & $\begin{array}{l}\text { Peguy } \\
\text { angan }\end{array}$ & $\begin{array}{l}1 \\
0 \\
\end{array}$ & $\begin{array}{l}6 \\
0 \\
\end{array}$ & $\begin{array}{l}3 \\
0 \\
\end{array}$ & 0 & 0 & 0 & 0 & 0 & 0 & 0 & 0 & 0 & 0 & 0 & 0 & 0 & 0 & 0 & 0 & 0 & 0 & 0 & 0 & 0 & 0 & 0 & 0 & 0 & 0 & 0 & 0 & 0 & 0 \\
\hline $\begin{array}{l}2 \\
3\end{array}$ & Tonja & $\begin{array}{l}4 \\
0\end{array}$ & $\begin{array}{l}6 \\
0\end{array}$ & $\begin{array}{l}1 \\
1 \\
0\end{array}$ & 0 & $\begin{array}{l}4 \\
0\end{array}$ & 0 & 0 & 0 & 0 & 0 & 0 & 0 & 0 & 0 & 0 & 0 & $\begin{array}{l}2 \\
0\end{array}$ & 0 & $\begin{array}{l}1 \\
0\end{array}$ & 0 & 0 & 0 & 0 & 0 & 0 & 0 & 0 & 0 & 0 & 0 & 0 & 0 & 0 \\
\hline $\begin{array}{l}2 \\
4\end{array}$ & $\begin{array}{l}\text { Padan } \\
\text { gsamb } \\
\text { ian }\end{array}$ & $\begin{array}{l}1 \\
0 \\
0\end{array}$ & $\begin{array}{l}4 \\
0\end{array}$ & $\begin{array}{l}9 \\
0\end{array}$ & $\begin{array}{l}4 \\
0\end{array}$ & $\begin{array}{l}1 \\
0 \\
0\end{array}$ & 0 & 0 & 0 & 0 & 0 & 0 & 0 & 0 & 0 & 0 & 0 & 0 & 0 & 0 & 0 & 0 & 0 & $\begin{array}{l}1 \\
0\end{array}$ & 0 & 0 & 0 & $\begin{array}{l}1 \\
0\end{array}$ & $\begin{array}{l}1 \\
0\end{array}$ & $\begin{array}{l}2 \\
0\end{array}$ & 0 & 0 & 0 & 0 \\
\hline $\begin{array}{l}2 \\
5\end{array}$ & $\begin{array}{l}\text { Tegal } \\
\text { harum }\end{array}$ & $\begin{array}{l}1 \\
2 \\
0 \\
\end{array}$ & $\begin{array}{l}3 \\
4 \\
0 \\
\end{array}$ & $\begin{array}{l}3 \\
3 \\
0 \\
\end{array}$ & $\begin{array}{l}9 \\
0\end{array}$ & $\begin{array}{l}2 \\
9 \\
0 \\
\end{array}$ & 0 & 0 & 0 & 0 & 0 & 0 & $\begin{array}{l}2 \\
0\end{array}$ & 0 & 0 & 0 & 0 & $\begin{array}{l}2 \\
0\end{array}$ & $\begin{array}{l}1 \\
0\end{array}$ & $\begin{array}{l}4 \\
0\end{array}$ & $\begin{array}{l}1 \\
0\end{array}$ & 0 & 0 & $\begin{array}{l}1 \\
0\end{array}$ & 0 & 0 & 0 & $\begin{array}{l}2 \\
0\end{array}$ & 0 & 0 & 0 & 0 & 0 & $\begin{array}{l}1 \\
0\end{array}$ \\
\hline $\begin{array}{l}2 \\
6\end{array}$ & $\begin{array}{l}\text { Dauhp } \\
\text { uri }\end{array}$ & $\begin{array}{l}9 \\
0\end{array}$ & $\begin{array}{l}2 \\
3 \\
0 \\
\end{array}$ & $\begin{array}{l}4 \\
2 \\
0 \\
\end{array}$ & $\begin{array}{l}1 \\
2 \\
0\end{array}$ & $\begin{array}{l}2 \\
6 \\
0 \\
\end{array}$ & 0 & 0 & 0 & 0 & 0 & 0 & 0 & 0 & 0 & 0 & 0 & $\begin{array}{l}3 \\
0\end{array}$ & $\begin{array}{l}1 \\
0\end{array}$ & $\begin{array}{l}4 \\
0\end{array}$ & 0 & 0 & 0 & 0 & 0 & $\begin{array}{l}1 \\
0\end{array}$ & 0 & 0 & 0 & $\begin{array}{l}1 \\
0\end{array}$ & 0 & 0 & 0 & 0 \\
\hline $\begin{array}{l}2 \\
7\end{array}$ & $\begin{array}{l}\text { Giany } \\
\text { ar }\end{array}$ & $\begin{array}{l}1 \\
9 \\
0\end{array}$ & $\begin{array}{l}1 \\
1 \\
0\end{array}$ & $\begin{array}{l}1 \\
7 \\
0\end{array}$ & $\begin{array}{l}1 \\
0\end{array}$ & $\begin{array}{l}6 \\
0\end{array}$ & 0 & 0 & 0 & 0 & 0 & 0 & 0 & 0 & 0 & 0 & 0 & $\begin{array}{l}1 \\
0\end{array}$ & 0 & $\begin{array}{l}1 \\
0\end{array}$ & 0 & 0 & 0 & 0 & 0 & 0 & 0 & 0 & $\begin{array}{l}9 \\
0\end{array}$ & $\begin{array}{l}5 \\
4\end{array}$ & $\begin{array}{l}8 \\
9\end{array}$ & $\begin{array}{l}4 \\
8\end{array}$ & $\begin{array}{l}1 \\
1\end{array}$ & $\begin{array}{l}7 \\
8\end{array}$ \\
\hline $\begin{array}{l}2 \\
8\end{array}$ & $\begin{array}{l}\text { Klung } \\
\text { kung }\end{array}$ & $\begin{array}{l}1 \\
0\end{array}$ & $\begin{array}{l}1 \\
0\end{array}$ & $\begin{array}{l}2 \\
0\end{array}$ & 0 & 0 & 0 & 0 & 0 & 0 & 0 & 0 & 0 & 0 & 0 & 0 & 0 & 0 & 0 & 0 & 0 & 0 & 0 & 0 & 0 & 0 & 0 & $\begin{array}{l}8 \\
0\end{array}$ & 0 & $\begin{array}{l}2 \\
9\end{array}$ & $\begin{array}{l}3 \\
3\end{array}$ & $\begin{array}{l}1 \\
9\end{array}$ & 4 & $\begin{array}{l}2 \\
2\end{array}$ \\
\hline $\begin{array}{l}2 \\
9 \\
\end{array}$ & $\begin{array}{l}\text { Karan } \\
\text { gasem }\end{array}$ & $\begin{array}{l}2 \\
0 \\
\end{array}$ & $\begin{array}{l}4 \\
0 \\
\end{array}$ & $\begin{array}{l}4 \\
0 \\
\end{array}$ & 0 & 0 & 0 & 0 & 0 & 0 & 0 & 0 & 0 & 0 & 0 & 0 & 0 & 0 & 0 & 0 & 0 & 0 & 0 & 0 & 0 & 0 & $\begin{array}{l}1 \\
0 \\
\end{array}$ & $\begin{array}{l}4 \\
8 \\
\end{array}$ & $\begin{array}{l}2 \\
9 \\
\end{array}$ & 0 & $\begin{array}{l}3 \\
3 \\
\end{array}$ & $\begin{array}{l}4 \\
2 \\
\end{array}$ & 8 & $\begin{array}{l}2 \\
9 \\
\end{array}$ \\
\hline $\begin{array}{l}3 \\
0\end{array}$ & Bangli & $\begin{array}{l}3 \\
0 \\
\end{array}$ & $\begin{array}{l}2 \\
0 \\
\end{array}$ & $\begin{array}{l}1 \\
0 \\
\end{array}$ & 0 & 0 & 0 & 0 & 0 & 0 & 0 & 0 & 0 & 0 & 0 & 0 & $\begin{array}{l}1 \\
0\end{array}$ & 0 & 0 & 0 & 0 & 0 & 0 & 0 & 0 & 0 & 0 & $\begin{array}{l}8 \\
0 \\
\end{array}$ & $\begin{array}{l}3 \\
4 \\
\end{array}$ & $\begin{array}{l}3 \\
4 \\
\end{array}$ & 0 & $\begin{array}{l}3 \\
0 \\
\end{array}$ & 6 & $\begin{array}{l}3 \\
3 \\
\end{array}$ \\
\hline $\begin{array}{l}3 \\
1 \\
\end{array}$ & $\begin{array}{l}\text { Bulele } \\
\text { ng }\end{array}$ & 0 & $\begin{array}{l}4 \\
0 \\
\end{array}$ & $\begin{array}{l}2 \\
0 \\
\end{array}$ & $\begin{array}{l}1 \\
0 \\
\end{array}$ & $\begin{array}{l}2 \\
0 \\
\end{array}$ & 0 & 0 & 0 & 0 & 0 & 0 & 0 & 0 & 0 & 0 & 0 & 0 & 0 & 0 & 0 & $\begin{array}{l}1 \\
0 \\
\end{array}$ & 0 & 0 & 0 & 0 & 0 & $\begin{array}{l}4 \\
4 \\
\end{array}$ & $\begin{array}{l}2 \\
0 \\
\end{array}$ & $\begin{array}{l}4 \\
3 \\
\end{array}$ & $\begin{array}{l}3 \\
0 \\
\end{array}$ & 0 & $\begin{array}{l}2 \\
3 \\
\end{array}$ & $\begin{array}{l}5 \\
1 \\
\end{array}$ \\
\hline $\begin{array}{l}3 \\
2 \\
\end{array}$ & $\begin{array}{l}\text { Jem } \\
\text { brana }\end{array}$ & 0 & $\begin{array}{l}5 \\
0 \\
\end{array}$ & $\begin{array}{l}5 \\
0 \\
\end{array}$ & 0 & 0 & 0 & 0 & 0 & 0 & 0 & 0 & $\begin{array}{l}1 \\
0 \\
\end{array}$ & 0 & 0 & 0 & 0 & 0 & 0 & 0 & 0 & 0 & 0 & 0 & 0 & 0 & 0 & $\begin{array}{l}1 \\
1 \\
\end{array}$ & 4 & 8 & 6 & $\begin{array}{l}2 \\
3 \\
\end{array}$ & 0 & $\begin{array}{l}1 \\
5 \\
\end{array}$ \\
\hline $\begin{array}{l}3 \\
3\end{array}$ & $\begin{array}{l}\text { Taban } \\
\text { an }\end{array}$ & $\begin{array}{l}1 \\
5 \\
0\end{array}$ & $\begin{array}{l}8 \\
0\end{array}$ & $\begin{array}{l}7 \\
0\end{array}$ & $\begin{array}{l}6 \\
0\end{array}$ & $\begin{array}{l}7 \\
0\end{array}$ & 0 & 0 & 0 & 0 & 0 & 0 & $\begin{array}{l}2 \\
0\end{array}$ & 0 & 0 & 0 & 0 & 0 & 0 & 0 & 0 & 0 & 0 & 0 & 0 & 0 & 0 & $\begin{array}{l}7 \\
1\end{array}$ & $\begin{array}{l}2 \\
3\end{array}$ & $\begin{array}{l}3 \\
0\end{array}$ & $\begin{array}{l}3 \\
3\end{array}$ & $\begin{array}{l}5 \\
1\end{array}$ & $\begin{array}{l}1 \\
5\end{array}$ & 0 \\
\hline
\end{tabular}

Table 5: Road characteristics and AADT at early year [10]

\begin{tabular}{|c|l|l|l|l|l|l|}
\hline $\begin{array}{c}\text { Seg. } \\
\text { Nu. }\end{array}$ & \multicolumn{1}{|c|}{ Road segmen names } & $\begin{array}{c}\text { Length } \\
(\mathbf{K} \text { m) }\end{array}$ & $\begin{array}{c}\text { Average } \\
\text { Width (M) }\end{array}$ & $\begin{array}{c}\text { SDI } \\
\text { Average }\end{array}$ & $\begin{array}{c}\text { IRI } \\
\text { Average }\end{array}$ & $\begin{array}{c}\text { AAD } \\
\text { T }\end{array}$ \\
\hline 001 & Gilimanuk - Cekik & 3,041 & 10,928 & 2,42 & 3,307 & 5141 \\
\hline 002 & Cekik - Bts. Kota Negara & 27,224 & 7,139 & 13,28 & 3,354 & 22319 \\
\hline & Jln. A. Yani - Jln. Udayana (Negara) & 1,923 & 12,181 & 0,75 & 3,325 & 11819 \\
\hline 003 & Bts. Kota Negara - Pekutatan & 20,445 & 7,330 & 0,32 & 3,285 & 6880 \\
\hline & Jln. Sudirman, Gajahmada (Negara) & 4,466 & 9,181 & 2,22 & 3,337 & 13001 \\
\hline 004 & Pekutatan - Antosari & 29,964 & 7,198 & 6,81 & 3,491 & 15807 \\
\hline 005 & Antosari - Bts. Kota Tabanan & 17,262 & 8,086 & 12,11 & 3,621 & 22689 \\
\hline & Simp. Kediri - Pesiapan (Tabanan) & 4,020 & 17,776 & 2,56 & 3,628 & 32028 \\
\hline 006 & Bts. Kota Tabanan - Mengwitani & 1,462 & 13,000 & 1,00 & 3,240 & 50795 \\
\hline & Jln. A. Yani (Tabanan) & 2,025 & 11,900 & 0,71 & 3,785 & 43812 \\
\hline 007 & Mengwitani - Bts. Kota Denpasar & 7,385 & 14,534 & 10,88 & 3,018 & 64924 \\
\hline & Jln. Cokroaminoto (Dps) & 3,826 & 11,132 & 25,64 & 2,870 & 33975 \\
\hline & Jln. Cokroaminoto (Dps) & 0,979 & 11,000 & 19,50 & 3,263 & 53609 \\
\hline & Jln. Sutomo (Dps) & 0,936 & 12,500 & 0,00 & 2,500 & 28094 \\
\hline & Jln. Setiabudi (Dps) & 0,770 & 10,000 & 0,00 & 4,113 & 20616 \\
\hline
\end{tabular}


International Journal of Trend in Scientific Research and Development (IJTSRD) | ISSN: 2456-647

\begin{tabular}{|c|c|c|c|c|c|c|}
\hline & Jln. Wahidin (Dps) & 0,232 & 8,000 & 0,00 & 4,133 & 30654 \\
\hline & Jln. Thamrin (Dps) & 0,376 & 9,000 & 11,25 & 3,875 & 21917 \\
\hline 008 & Sp.Cokroaminoto - Sp.Kerobokan & 3,788 & 14,000 & 0,92 & 3,661 & 47775 \\
\hline 009 & Jln. GunungAgung - AksesKargo & 4,424 & 13,435 & 2,33 & 3,319 & 21474 \\
\hline 010 & Jln. Western Ring Road (Sp.GatotSubroto & 4,460 & 14,000 & 1,00 & 3,000 & 21474 \\
\hline 011 & Kuta - Banjar Taman & 5,467 & 14,000 & 8,00 & 3,379 & 21474 \\
\hline 012 & Denpasar - Tuban & 10,781 & 8,677 & 0,90 & 3,272 & 23140 \\
\hline 013 & Simp. Kuta - TuguNgurah Rai & 2,726 & 16,289 & 1,61 & 3,657 & 26367 \\
\hline 014 & Sp. Lap. Terbang (Dps) - TuguNgurah Ra & 0,350 & 18,000 & 0,00 & 3,050 & 20037 \\
\hline 015 & TuguNgurah Rai - Nusa Dua & 9,536 & 13,700 & 8,20 & 2,602 & 47469 \\
\hline 016 & SimpangKuta - Simp. Pesanggaran & 3,693 & 13,000 & 23,38 & 3,419 & 38948 \\
\hline 017 & Simp.Pesanggaran - GerbangBenoa & 0,604 & 19,000 & 2,14 & 4,067 & 7887 \\
\hline 018 & SimpangPesanggaran - Simpang Sanur & 8,390 & 13,824 & 4,61 & 3,434 & 23452 \\
\hline 019 & Simpang Sanur - SimpangTohpati & 4,390 & 13,023 & 8,86 & 2,805 & 24974 \\
\hline 020 & Sp.Cokroaminoto - Sp.Tohpati (Jln. G. Su & 5,357 & 13,198 & 0,91 & 3,194 & 24712 \\
\hline \multirow[t]{2}{*}{021} & Sp. PantaiSiut - Kosamba & 11,806 & 7,000 & 0,74 & 3,011 & 55683 \\
\hline & Sp. Tohpati - Sp. PantaiSiut & 15,899 & 16,000 & 2,34 & 2,892 & 55683 \\
\hline 022 & Sp. Tohpati - Sakah & 12,965 & 11,452 & 0,85 & 3,740 & 55683 \\
\hline 023 & Sakah - Blahbatu & 3,027 & 8,111 & 0,48 & 3,603 & 26302 \\
\hline 024 & Blahbatu - Semebaung & 3,765 & 8,433 & 0,00 & 3,162 & 28347 \\
\hline \multirow[t]{3}{*}{025} & Semebaung - Bts. Kota Gianyar & 2,095 & 8,050 & 0,00 & 3,086 & 31158 \\
\hline & Jln. CiungWanara (Gianyar) & 0,537 & 14,000 & 0,00 & 2,950 & 31158 \\
\hline & Jln. Astina Utara (Gianyar) & 0,398 & 10,000 & 0,00 & 4,300 & 31158 \\
\hline \multirow[t]{3}{*}{026} & Bts. Kota Gianyar - Sidan & 1,253 & 12,000 & 0,00 & 3,131 & 31965 \\
\hline & Jln. Ngurah Rai (Gianyar) & 0,667 & 7,000 & 2,14 & 3,257 & 31965 \\
\hline & Jln. AstinaTimur (Gianyar) & 0,984 & 8,228 & 0,00 & 4,056 & 31965 \\
\hline \multirow[t]{2}{*}{027} & Sidan - Bts. Kota Klungkung & 7,180 & 7,500 & 7,43 & 3,244 & 13311 \\
\hline & $\begin{array}{l}\text { Jln. UntungSuropati, Flamboyan } \\
\text { (Semarap }\end{array}$ & 1,769 & 8,335 & 2,78 & 3,254 & 13311 \\
\hline \multirow[t]{2}{*}{028} & $\begin{array}{l}\text { Bts. Kota Klungkung - Kosamba (Bts. } \\
\text { Kab. }\end{array}$ & 10,101 & 11,300 & 1,62 & 3,476 & 31697 \\
\hline & Jln. Diponegoro (Semarapura) & 0,815 & 7,251 & 0,00 & 3,247 & 31697 \\
\hline 029 & $\begin{array}{l}\text { Kosamba (Bts. Kab. Karangasem)- } \\
\text { Angente }\end{array}$ & 4,376 & 8,949 & 5,80 & 3,701 & 11587 \\
\hline 030 & Angentelu - Padangbai & 2,048 & 7,324 & 1,59 & 3,350 & 951 \\
\hline \multirow[t]{2}{*}{031} & Cekik-Seririt & 62,910 & 8,600 & 1,96 & 3,313 & 1578 \\
\hline & Jln. A. Yani - Jln. S. Parman (Seririt) & 0,741 & 7,892 & 0,00 & 3,440 & 1160 \\
\hline \multirow[t]{2}{*}{032} & Seririt - Bts. Kota Singaraja & 18,656 & 16,224 & 7,85 & 3,453 & 15596 \\
\hline & Jln. Gajahmada - Dr. Sutomo - A. Yani (S & 4,090 & 7,708 & 0,00 & 3,675 & 10857 \\
\hline \multirow[t]{2}{*}{033} & Bts. Kota Singaraja - Kubutambahan & 6,199 & 10,374 & 1,53 & 3,720 & 17764 \\
\hline & Jln. Ng. Rai Selatan - Jln. Pramuka - J1 & 6,007 & 7,004 & 1,56 & 3,102 & 13031 \\
\hline 034 & $\begin{array}{l}\text { Kubutambahan-Km } \\
\text { 124Dps(BonDalem/Ds. }\end{array}$ & 46,000 & 7,000 & 0,58 & 3,761 & 3750 \\
\hline \multirow[t]{2}{*}{035} & $\begin{array}{l}\text { Km } 124 \text { Dps (Bon Dalem/Ds. Tembok)- } \\
\text { Bts. }\end{array}$ & 30,637 & 9,027 & 0,90 & 3,327 & 8735 \\
\hline & Jln. UntungSurapati (Amlapura) & 2,825 & 6,656 & 16,38 & 3,031 & 4068 \\
\hline \multirow[t]{2}{*}{036} & Bts. Kota Amlapura - Angentelu & 20,331 & 7,431 & 6,02 & 3,671 & 16208 \\
\hline & Jln. Sudirman - A. Yani (Amlapura) & 2,584 & 9,871 & 1,11 & 3,271 & 16208 \\
\hline \multirow[t]{2}{*}{037} & Bts. Kota Singaraja - Mengwitani & 60,425 & 7,500 & 9,39 & 3,722 & 2564 \\
\hline & Jln. JelantikGingsir - Veteran (Singara & 3,425 & 10,000 & 4,29 & 3,745 & 632 \\
\hline 038 & Sp. 3 Mengwi - Beringkit & 0,413 & 9,108 & 0,00 & 4,050 & 632 \\
\hline
\end{tabular}


International Journal of Trend in Scientific Research and Development (IJTSRD) | ISSN: 2456-647

Table 6: Traffic forecasting by link-based approach

\begin{tabular}{|c|c|c|c|c|c|c|c|c|c|c|c|c|}
\hline \multirow{2}{*}{$\begin{array}{l}\mathrm{N} \\
\mathrm{u} .\end{array}$} & \multirow{2}{*}{ Name so Link } & \multicolumn{11}{|c|}{ VOLUME } \\
\hline & & 2015 & 2016 & 2017 & 2018 & 2019 & 2020 & 2021 & 2022 & 2023 & 2024 & 2025 \\
\hline 1 & Gilimanuk - Cekik & 319 & 329 & 338 & 349 & 359 & 370 & 381 & 392 & 404 & 416 & 429 \\
\hline 2 & Cekik - Bts. Kota Negara & 319 & 329 & 338 & 349 & 359 & 370 & 381 & 392 & 404 & 416 & 429 \\
\hline 3 & $\begin{array}{l}\text { Jln. A. Yani -Jln. } \\
\text { Udayana(Negara) }\end{array}$ & 319 & 329 & 338 & 349 & 359 & 370 & 381 & 392 & 404 & 416 & 429 \\
\hline 4 & $\begin{array}{l}\text { Bts. KotaNegara- } \\
\text { PekutatanGajahmada }\end{array}$ & 2134 & 2198 & 2264 & 2332 & 2402 & 2474 & 2548 & 2625 & 2703 & 2784 & 2868 \\
\hline 5 & Jln. Sudirman, (Negara) & 2134 & 2198 & 2264 & 2332 & 2402 & 2474 & 2548 & 2625 & 2703 & 2784 & 2868 \\
\hline 6 & Pekutatan-Antosari & 2134 & 2198 & 2264 & 2332 & 2402 & 2474 & 2548 & 2625 & 2703 & 2784 & 2868 \\
\hline 7 & $\begin{array}{l}\text { Antosari - Bts. Kota } \\
\text { Tabanan }\end{array}$ & 2134 & 2198 & 2264 & 2332 & 2402 & 2474 & 2548 & 2625 & 2703 & 2784 & 2868 \\
\hline 8 & $\begin{array}{l}\text { Simp. Kediri - Pesiapan } \\
\text { (Tabanan) }\end{array}$ & 2134 & 2198 & 2264 & 2332 & 2402 & 2474 & 2548 & 2625 & 2703 & 2784 & 2868 \\
\hline 9 & $\begin{array}{l}\text { Bts. KotaTabanan- } \\
\text { Mengwitani }\end{array}$ & 11066 & 11398 & 11740 & 12092 & 12455 & 12829 & 13213 & 13610 & 14018 & 14439 & 14872 \\
\hline 10 & Jln. A. Yani (Tabanan) & 11066 & 11398 & 11740 & 12092 & 12455 & 12829 & 13213 & 13610 & 14018 & 14439 & 14872 \\
\hline 11 & $\begin{array}{l}\text { Mengwitani -Bts.Kota } \\
\text { Denpasar }\end{array}$ & 20834 & 21459 & 22103 & 22766 & 23449 & 24152 & 24877 & 25623 & 26392 & 27184 & 27999 \\
\hline 12 & Jln. Cokroaminoto(Dps) & 20834 & 21459 & 22103 & 22766 & 23449 & 24152 & 24877 & 25623 & 26392 & 27184 & 27999 \\
\hline 13 & Jln. Cokroaminoto(Dps) & 20834 & 21459 & 22103 & 22766 & 23449 & 24152 & 24877 & 25623 & 26392 & 27184 & 27999 \\
\hline 14 & Jln.Sutomo(Dps) & 20834 & 21459 & 22103 & 22766 & 23449 & 24152 & 24877 & 25623 & 26392 & 27184 & 27999 \\
\hline 15 & Jln. Setial & 20834 & 21459 & 22103 & 22766 & 23449 & 24152 & 24877 & 25623 & 26392 & 27184 & 27999 \\
\hline 16 & Jln. Wahic & 20834 & 21459 & 22103 & 22766 & 23449 & 24152 & 24877 & 25623 & 26392 & 27184 & 27999 \\
\hline 17 & Jln. Tham & 20834 & 21459 & 22103 & 22766 & 23449 & 24152 & 24877 & 25623 & 26392 & 27184 & 27999 \\
\hline 18 & $\begin{array}{l}\text { Sp.Cokroaminoto- } \\
\text { Sp.Kerobokan }\end{array}$ & 17963 & 18502 & 19057 & 19629 & 20218 & 20824 & 21449 & 22092 & 22755 & 23438 & 24141 \\
\hline 19 & $\begin{array}{l}\text { Jln. GunungAgung- } \\
\text { AksesKargo }\end{array}$ & 25542 & 26308 & 27098 & 27910 & 28748 & 29610 & 30498 & 31413 & 32356 & 33327 & 34326 \\
\hline 20 & $\begin{array}{l}\text { Jln. Western Ring Road } \\
\text { (Sp. Gato Subro to }\end{array}$ & 25487 & 26252 & 27039 & 27850 & 28686 & 29546 & 30433 & 31346 & 32286 & 33255 & 34252 \\
\hline 21 & Kuta-BanjarTaman & 33572 & 34579 & 35617 & 36685 & 37786 & 38919 & 40087 & 41289 & 42528 & 43804 & 45118 \\
\hline 22 & Denpasar- Tuban & 59895 & 61692 & 63543 & 65449 & 67412 & 69435 & 71518 & 73663 & 75873 & 78149 & 80494 \\
\hline 23 & $\begin{array}{l}\text { Simp. Kuta - Tugu } \\
\text { NgurahRai }\end{array}$ & 73854 & 76070 & 78352 & 80702 & 83123 & 85617 & 88186 & 90831 & 93556 & 96363 & 99254 \\
\hline 24 & $\begin{array}{l}\text { Sp. Lap. Terbang(Dps)- } \\
\text { TuguNgurah Ra }\end{array}$ & 33275 & 34273 & 35301 & 36360 & 37451 & 38575 & 39732 & 40924 & 42152 & 43416 & 44719 \\
\hline 25 & $\begin{array}{l}\text { TuguNgurah Rai-Nusa } \\
\text { Dua }\end{array}$ & 55825 & 57500 & 59225 & 61001 & 62832 & 64716 & 66658 & 68658 & 70717 & 72839 & 75024 \\
\hline 26 & $\begin{array}{l}\text { SimpangKuta-Simp. } \\
\text { Pesanggaran }\end{array}$ & 71137 & 73271 & 75469 & 77733 & 80065 & 82467 & 84941 & 87490 & 90114 & 92818 & 95602 \\
\hline 27 & $\begin{array}{l}\text { Simp.Pesanggaran- } \\
\text { GerbangBenoa }\end{array}$ & 9581 & 9868 & 10164 & 10469 & 10783 & 11107 & 11440 & 11783 & 12137 & 12501 & 12876 \\
\hline 28 & $\begin{array}{l}\text { SimpangPesanggaran- } \\
\text { Simpang Sanur }\end{array}$ & 29095 & 29968 & 30867 & 31793 & 32747 & 33729 & 34741 & 35783 & 36857 & 37962 & 39101 \\
\hline 29 & $\begin{array}{l}\text { Simpang Sanur-Simpang } \\
\text { Tohpati }\end{array}$ & 15334 & 15794 & 16268 & 16756 & 17259 & 17776 & 18310 & 18859 & 19425 & 20007 & 20608 \\
\hline 30 & $\begin{array}{l}\text { Sp.Cokroaminoto- } \\
\text { Sp.Tohpati (Jln. G. Su }\end{array}$ & 17094 & 17607 & 18135 & 18679 & 19239 & 19817 & 20411 & 21023 & 21654 & 22304 & 22973 \\
\hline 31 & Sp. PantaiSiut-Kosamba & 7018 & 7229 & 7445 & 7669 & 7899 & 8136 & 8380 & 8631 & 8890 & 9157 & 9432 \\
\hline 32 & Sp.Tohpa & 7018 & 7229 & 7445 & 7669 & 7899 & 8136 & 8380 & 8631 & 8890 & 9157 & 9432 \\
\hline 33 & Sp. Tohpati-Sakah & 20482 & 21096 & 21729 & 22381 & 23053 & 23744 & 24457 & 25190 & 25946 & 26724 & 27526 \\
\hline 34 & Sakah-Blahbatu & 19514 & 20099 & 20702 & 21323 & 21963 & 22622 & 23301 & 24000 & 24720 & 25461 & 26225 \\
\hline 35 & Blahbat & 19514 & 20099 & 20702 & 21323 & 21963 & 22622 & 23301 & 24000 & 24720 & 25461 & 26225 \\
\hline 36 & $\begin{array}{l}\text { Semebaung - Bts. Kota } \\
\text { Gianyar }\end{array}$ & 19514 & 20099 & 20702 & 21323 & 21963 & 22 & 23301 & 24000 & 24720 & 25461 & 26225 \\
\hline 37 & Jln.CiungWanara & 19514 & 20099 & 20702 & 21323 & 21963 & 22622 & 23301 & 24000 & 24720 & 25461 & 26225 \\
\hline
\end{tabular}


International Journal of Trend in Scientific Research and Development (IJTSRD) | ISSN: 2456-647

\begin{tabular}{|c|c|c|c|c|c|c|c|c|c|c|c|c|}
\hline & (Gianyar) & & & & & & & & & & & \\
\hline 38 & Jln.AstinaUtara(Gianyar) & 19514 & 20099 & 20702 & 21323 & 21963 & 22622 & 23301 & 24000 & 24720 & 25461 & 26225 \\
\hline 39 & Bts. Kota Gianyar-Sidan & 2475 & 2549 & 2626 & 2704 & 2786 & 2869 & 2955 & 3044 & 3135 & 3229 & 3326 \\
\hline 40 & Jln. NgurahRai(Gianyar) & 2475 & 2549 & 2626 & 2704 & 2786 & 2869 & 2955 & 3044 & 3135 & 3229 & 3326 \\
\hline 41 & $\begin{array}{l}\text { Jln.AstinaTimur } \\
\text { (Gianyar) }\end{array}$ & 2475 & 2549 & 2626 & 2704 & 2786 & 2869 & 2955 & 3044 & 3135 & 3229 & 3326 \\
\hline 42 & $\begin{array}{l}\text { Sidan -Bts. Kota } \\
\text { Klungkung }\end{array}$ & 2475 & 2549 & 2626 & 2704 & 2786 & 2869 & 2955 & 3044 & 3135 & 3229 & 3326 \\
\hline 43 & $\begin{array}{l}\text { Jln.UntungSuropati, } \\
\text { Flamboyan (Semarap }\end{array}$ & 2475 & 2549 & 2626 & 2704 & 2786 & 2869 & 2955 & 3044 & 3135 & 3229 & 3326 \\
\hline 44 & $\begin{array}{l}\text { Bts. Kota Klungkung- } \\
\text { Kosamba (Bts.Kab. }\end{array}$ & 3531 & 3637 & 3746 & 3858 & 3974 & 4093 & 4216 & 4343 & 4473 & 4607 & 4745 \\
\hline 45 & $\begin{array}{l}\text { Jln. Diponegoro } \\
\text { (Semarapura) }\end{array}$ & 3531 & 3637 & 3746 & 3858 & 3974 & 4093 & 4216 & 4343 & 4473 & 4607 & 4745 \\
\hline 46 & $\begin{array}{l}\text { Kosamba(Bts.Kab.Karan } \\
\text { gasem) - Angente }\end{array}$ & 5709 & 5880 & 6057 & 6238 & 6426 & 6618 & 6817 & 7021 & 7232 & 7449 & 7672 \\
\hline 47 & Angentelu- Padangbai & 5709 & 5880 & 6057 & 6238 & 6426 & 6618 & 6817 & 7021 & 7232 & 7449 & 7672 \\
\hline 48 & Cekik-Seririt & 319 & 329 & 338 & 349 & 359 & 370 & 381 & 392 & 404 & 416 & 429 \\
\hline 49 & $\begin{array}{l}\text { Jln. A. Yani - } \\
\text { Jln.S.Parman (Seririt) }\end{array}$ & 319 & 329 & 338 & 349 & 359 & 370 & 381 & 392 & 404 & 416 & 429 \\
\hline 50 & Seririt-Bts.KotaSingaraja & 319 & 329 & 338 & 349 & 359 & 370 & 381 & 392 & 404 & 416 & 429 \\
\hline 51 & $\begin{array}{l}\text { Jln. Gajahmada- } \\
\text { Dr.Sutomo - A.Yani(s }\end{array}$ & 319 & 329 & 338 & 349 & 359 & 370 & 381 & 392 & 404 & 416 & 429 \\
\hline 52 & $\begin{array}{l}\text { Bts. KotaSingaraja - } \\
\text { Kubutambahan Pram }\end{array}$ & 1001 & 1031 & 1062 & 1094 & 1127 & 1160 & 1195 & 1231 & 1268 & 1306 & 1345 \\
\hline 53 & $\begin{array}{l}\text { Jln. Ng. Rai Selatan- } \\
\text { Jln.uka-J1 }\end{array}$ & 1001 & 1031 & 1062 & 1094 & 1127 & 1160 & 1195 & 1231 & 1268 & 1306 & 1345 \\
\hline 54 & $\begin{array}{l}\text { Kubutambahan - Km } \\
124 \text { Dps (Bon Dalem/Ds. }\end{array}$ & 1001 & 1031 & 1062 & 1094 & 1127 & 1160 & 1195 & 1231 & 1268 & 1306 & 1345 \\
\hline 55 & $\begin{array}{l}\text { Km124Dps (Bon Dalem/ } \\
\text { Ds. Tembok)- Bts. }\end{array}$ & 594 & 612 & 630 & 649 & 669 & 689 & 709 & 731 & 752 & 775 & 798 \\
\hline 56 & $\begin{array}{l}\text { Jln. UntungSurapati } \\
\text { (Amlapura) }\end{array}$ & 594 & 612 & 630 & 649 & 669 & 689 & 709 & 731 & 752 & 775 & 798 \\
\hline 57 & $\begin{array}{l}\text { Bts. KotaAmlapura- } \\
\text { Angentelu }\end{array}$ & 5709 & 5880 & 6057 & 6238 & 6426 & 6618 & 6817 & 7021 & 7232 & 7449 & 7672 \\
\hline 58 & $\begin{array}{l}\text { Jln. Sudirman - A. Yani } \\
\text { (Amlapura) }\end{array}$ & 5709 & 5880 & 6057 & 6238 & 6426 & 6618 & 6817 & 7021 & 7232 & 7449 & 7672 \\
\hline 59 & $\begin{array}{l}\text { Bts. KotaSingaraja- } \\
\text { Mengwitani }\end{array}$ & 2981 & 3070 & 3163 & 3257 & 3355 & 3456 & 3559 & 3666 & 3776 & 3890 & 4006 \\
\hline 60 & $\begin{array}{l}\text { Jln. JelantikGingsir- } \\
\text { Veteran (Singara }\end{array}$ & 2981 & 3070 & 3163 & 3257 & 3355 & 3456 & 3559 & 3666 & 3776 & 3890 & 4006 \\
\hline 61 & Sp. 3 Mengwi-Beringkit & 10472 & 10786 & 11110 & 11443 & 11786 & 12140 & 12504 & 12879 & 13266 & 13664 & 14073 \\
\hline
\end{tabular}

Table 7: Total road maintenance cost needs every year with link-based

$$
\text { Total maintenance cost needs every years(Rp.1.000.000,-) }
$$

\begin{tabular}{|l|l|l|l|l|l|l|l|l|l|l|l|l|}
\hline $\begin{array}{l}\text { Analysis } \\
\text { Types }\end{array}$ & 2015 & 2016 & 2017 & 2018 & 2019 & 2020 & 2021 & 2022 & 2023 & 2024 & 2025 & \\
\hline $\begin{array}{l}\text { Linkbased } \\
20\end{array}$ & 33,2 & 32,6 & 32,6 & 57,2 & 74,0 & 85,1 & 72,2 & 106,0 & 119,5 & 225,7 & 225,2 & $1,063,8$ \\
& 26 & 56 & 56 & 63 & 33 & 20 & 85 & 90 & 70 & 54 & 04 & 58 \\
\hline Linkbased & 33,2 & 32,6 & 31,3 & 43,4 & 46,1 & 46,1 & 47,4 & 47,42 & 53,67 & 68,17 & 79,03 & 528,73 \\
40 & 26 & 56 & 68 & 87 & 39 & 39 & 21 & 1 & 3 & 9 & 0 & 8 \\
\hline Linkbased & 33,2 & 31,6 & 31,6 & 32,6 & 32,6 & 32,6 & 33,9 & 32,65 & 32,65 & 37,48 & 42,49 & 373,70 \\
60 & 26 & 48 & 48 & 56 & 56 & 56 & 38 & 0 & 0 & 6 & 6 & 9 \\
\hline Linkbased & 33,2 & 28,7 & 28,7 & 28,7 & 28,7 & 28,7 & 28,7 & 28,77 & 28,77 & 33,60 & 33,60 & 330,62 \\
80 & 26 & 72 & 72 & 72 & 72 & 72 & 72 & 2 & 2 & 8 & 8 & 0 \\
\hline
\end{tabular}


International Journal of Trend in Scientific Research and Development (IJTSRD) | ISSN: 2456-647

Table 9: The differences in link traffic flow (link-based vs network-based)

\begin{tabular}{|c|c|c|c|c|c|c|c|c|}
\hline \multirow{2}{*}{ No } & \multirow{2}{*}{ Length(m) } & \multirow{2}{*}{ IRI2015 } & IRI2020 & \multicolumn{2}{|c|}{ LinkBased_20 approach } & \multicolumn{2}{|c|}{ NetworkBased_20 } \\
\cline { 5 - 9 } & & & & Approach \\
\hline 15 & $\begin{array}{c}\text { Jln. Setiabudi } \\
\text { (Dps) }\end{array}$ & 0.77 & 4.21 & 4.74 & 20,834 & 24,152 & 20,834 & 22,979 \\
\hline 16 & $\begin{array}{c}\text { Jln. Wahidin } \\
\text { (Dps) }\end{array}$ & 0.23 & 4.23 & 4.76 & 20,834 & 24,152 & 20,834 & 22,979 \\
\hline 17 & $\begin{array}{c}\text { Jln. Thamrin } \\
\text { (Dps) }\end{array}$ & 0.38 & 3.97 & 4.50 & 20,834 & 24,152 & 20,834 & 22,978 \\
\hline
\end{tabular}

Table 10: The total road maintenance cost per year with network-based

\begin{tabular}{|c|c|c|c|c|c|c|c|c|c|c|c|c|}
\hline \multirow{2}{*}{$\begin{array}{c}\text { Analysis } \\
\text { Types }\end{array}$} & \multicolumn{11}{|c|}{ Total Maintenance Cost (Fiscal Need) per Years (Rp. 1.000.000,-) } & \multirow{2}{*}{$\begin{array}{c}\text { Total } \\
\text { cost(Rp.) }\end{array}$} \\
\hline & 2015 & 2016 & 2017 & 2018 & 2019 & 2020 & 2021 & 2022 & 2023 & 2024 & 2025 & \\
\hline $\begin{array}{c}\text { Networkb } \\
\text { ased } 20\end{array}$ & $\begin{array}{c}33,2 \\
26\end{array}$ & $\begin{array}{c}32,6 \\
56\end{array}$ & $\begin{array}{c}32,6 \\
56\end{array}$ & $\begin{array}{c}57,2 \\
63\end{array}$ & $\begin{array}{c}59,9 \\
15\end{array}$ & $\begin{array}{c}66,1 \\
67\end{array}$ & $\begin{array}{c}66,1 \\
67\end{array}$ & $\begin{array}{c}90,2 \\
67\end{array}$ & $\begin{array}{c}93,9 \\
09\end{array}$ & $\begin{array}{l}131 \\
420\end{array}$ & $\begin{array}{l}117 \\
777\end{array}$ & 781,422 \\
\hline $\begin{array}{l}\text { Networkb } \\
\text { ased } 40\end{array}$ & $\begin{array}{c}33,2 \\
26\end{array}$ & $\begin{array}{c}32,6 \\
56\end{array}$ & $\begin{array}{c}31,3 \\
68\end{array}$ & $\begin{array}{c}38,5 \\
27\end{array}$ & $\begin{array}{c}41,1 \\
78\end{array}$ & $\begin{array}{c}41,1 \\
78\end{array}$ & $\begin{array}{c}41,1 \\
78\end{array}$ & $\begin{array}{c}59,4 \\
38\end{array}$ & $\begin{array}{c}59,4 \\
38\end{array}$ & $\begin{array}{c}69,1 \\
09\end{array}$ & $\begin{array}{c}74,1 \\
19\end{array}$ & 521,417 \\
\hline $\begin{array}{c}\text { Networkb } \\
\text { ased } 60\end{array}$ & $\begin{array}{c}33,2 \\
26\end{array}$ & $\begin{array}{c}31,6 \\
48\end{array}$ & $\begin{array}{c}30,3 \\
59\end{array}$ & $\begin{array}{c}37,7 \\
36\end{array}$ & $\begin{array}{c}30,5 \\
77\end{array}$ & $\begin{array}{c}37,7 \\
36\end{array}$ & $\begin{array}{c}30,5 \\
77\end{array}$ & $\begin{array}{c}48,8 \\
37\end{array}$ & $\begin{array}{c}48,8 \\
37\end{array}$ & $\begin{array}{c}48,8 \\
37\end{array}$ & $\begin{array}{c}53,8 \\
47\end{array}$ & 432,214 \\
\hline $\begin{array}{c}\text { Networkb } \\
\text { ased } 80\end{array}$ & $\begin{array}{c}33,2 \\
26\end{array}$ & $\begin{array}{c}32,6 \\
56\end{array}$ & $\begin{array}{c}28,7 \\
72\end{array}$ & $\begin{array}{c}28,7 \\
72\end{array}$ & $\begin{array}{c}28,7 \\
72\end{array}$ & $\begin{array}{c}28,7 \\
72\end{array}$ & $\begin{array}{c}28,7 \\
72\end{array}$ & $\begin{array}{c}28,7 \\
72\end{array}$ & $\begin{array}{c}28,7 \\
72\end{array}$ & $\begin{array}{c}28,7 \\
72\end{array}$ & $\begin{array}{c}28,7 \\
72\end{array}$ & 332 \\
\hline
\end{tabular}

Table 14: Differences maintenance program due to differences in forecasts traffic flow

\begin{tabular}{|c|c|c|c|c|c|c|c|c|c|c|c|c|}
\hline \multirow[b]{2}{*}{$\begin{array}{l}\text { Ye } \\
\text { ar }\end{array}$} & \multicolumn{6}{|c|}{ Networkbased 60} & \multicolumn{6}{|c|}{ Linkbased 60} \\
\hline & $\begin{array}{l}\mathrm{Nu} \\
.\end{array}$ & Link & $\begin{array}{l}\text { Lengh } \\
\mathrm{t}(\mathrm{Km}) \\
\end{array}$ & $\begin{array}{l}\text { Width } \\
\text { (M) }\end{array}$ & $\begin{array}{l}\text { Treat } \\
\text { ment }\end{array}$ & $\begin{array}{l}\text { Cost } \\
\text { (Rp.) }\end{array}$ & $\begin{array}{l}\mathrm{Nu} \\
. \\
\end{array}$ & Link & $\begin{array}{l}\text { Lenght } \\
(\mathrm{Km})\end{array}$ & $\begin{array}{l}\text { Widt } \\
\mathrm{h}(\mathrm{m})\end{array}$ & $\begin{array}{l}\text { Trea } \\
t \text { of }\end{array}$ & $\begin{array}{l}\text { Cost } \\
(\mathrm{R} p) \\
\end{array}$ \\
\hline \multirow{5}{*}{$\begin{array}{l}20 \\
22\end{array}$} & 33 & $\begin{array}{l}\text { Sp. } \\
\text { Tohpati } \\
\text { - Sakah }\end{array}$ & 12,97 & 11,5 & $\begin{array}{l}\text { Preve } \\
\text { ntif }\end{array}$ & $\begin{array}{l}17.69 \\
0.730\end{array}$ & 27 & $\begin{array}{l}\text { Simp. } \\
\text { Pesanggara } \\
\text { n Gerbang } \\
\text { Benoa }\end{array}$ & 0,60 & 19,0 & $\begin{array}{l}\text { Prev } \\
\text { entif }\end{array}$ & $\begin{array}{l}824 . \\
157\end{array}$ \\
\hline & 13 & $\begin{array}{l}\text { Jln. } \\
\text { Cokroa } \\
\text { minoto } \\
(\mathrm{Dps})\end{array}$ & 0,98 & 11,0 & $\begin{array}{l}\text { Preve } \\
\text { ntif }\end{array}$ & $\begin{array}{l}1.335 \\
.845\end{array}$ & 15 & $\begin{array}{l}\text { Jln. } \\
\text { Setiabudi } \\
\text { (Dps) }\end{array}$ & 0,77 & 10,0 & $\begin{array}{l}\text { Prev } \\
\text { entif }\end{array}$ & $\begin{array}{l}1.05 \\
0.66 \\
4\end{array}$ \\
\hline & 15 & $\begin{array}{l}\text { Jln. } \\
\text { Setiabu } \\
\text { di(Dps) }\end{array}$ & 0,77 & 10,0 & $\begin{array}{l}\text { Preve } \\
\text { ntif }\end{array}$ & $\begin{array}{l}1.050 \\
.664\end{array}$ & 16 & $\begin{array}{l}\text { Jln. } \\
\text { Wahidin } \\
\text { (Dps) }\end{array}$ & 0,23 & 8,0 & $\begin{array}{l}\text { Prev } \\
\text { entif }\end{array}$ & $\begin{array}{l}316 . \\
564\end{array}$ \\
\hline & 16 & $\begin{array}{l}\text { Jln. } \\
\text { Wahidi } \\
\text { n (Dps) }\end{array}$ & 0,23 & 8,0 & $\begin{array}{l}\text { Preve } \\
\text { ntif }\end{array}$ & $\begin{array}{l}316.5 \\
64\end{array}$ & 17 & $\begin{array}{l}\text { Jln. } \\
\text { Thamrin } \\
(\mathrm{Dps})\end{array}$ & 0,38 & 9,0 & $\begin{array}{l}\text { Prev } \\
\text { entif }\end{array}$ & $\begin{array}{l}513 . \\
052\end{array}$ \\
\hline & 17 & $\begin{array}{l}\text { Jln. } \\
\text { Thamri } \\
\text { n (Dps) }\end{array}$ & 0,38 & 9,0 & $\begin{array}{l}\text { Preve } \\
\text { ntif }\end{array}$ & $\begin{array}{l}513.0 \\
52\end{array}$ & 13 & $\begin{array}{l}\text { Jln. } \\
\text { Cokroamin } \\
\text { o to (Dps) }\end{array}$ & 0,98 & 11,0 & $\begin{array}{l}\text { Prev } \\
\text { entif }\end{array}$ & $\begin{array}{l}1.33 \\
5.84 \\
5 \\
\end{array}$ \\
\hline
\end{tabular}

